\title{
The Geo-Social Model: A Transdisciplinary Approach to Flow-Type Landslide Analysis and Prevention
}

\author{
Valentina Acuña ${ }^{1, *}$, Francisca Roldán ${ }^{2, *}$, Manuel Tironi ${ }^{1}$ and Leila Juzam ${ }^{1}$ \\ 1 Centro de Investigación para la Gestión Integrada del Riesgo de Desastres (CIGIDEN), Pontificia Universidad \\ Católica de Chile, Santiago 8320000, Chile; metironi@uc.cl (M.T.); leila.juzam@cigiden.cl (L.J.) \\ 2 Centro de Investigación para la Gestión Integrada del Riesgo de Desastres (CIGIDEN), Universidad Católica \\ del Norte, Antofagasta 1270709, Chile \\ * Correspondence: vmacuna@uc.cl (V.A.); francisca.roldan@cigiden.cl (F.R.); Tel.: +56-98-2184518 (V.A.); \\ +56-95-6479506 (F.R.)
}

Citation: Acuña, V.; Roldán, F.; Tironi, M.; Juzam, L. The Geo-Social Model: A Transdisciplinary Approach to Flow-Type Landslide Analysis and Prevention. Sustainability 2021, 13, 2501. https://doi.org/10.3390/su13052501

Academic Editor: Lucio Di Matteo

Received: 24 December 2020

Accepted: 13 February 2021

Published: 25 February 2021

Publisher's Note: MDPI stays neutral with regard to jurisdictional claims in published maps and institutional affiliations.

Copyright: (c) 2021 by the authors. Licensee MDPI, Basel, Switzerland. This article is an open access article distributed under the terms and conditions of the Creative Commons Attribution (CC BY) license (https:// creativecommons.org/licenses/by/ $4.0 /)$.

\begin{abstract}
Landslide disaster risks increase worldwide, particularly in urban areas. To design and implement more effective and democratic risk reduction programs, calls for transdisciplinary approaches have recently increased. However, little attention has been paid to the actual articulation of transdisciplinary methods and their associated challenges. To fill this gap, we draw on the case of the 1993 Quebrada de Macul disaster, Chile, to propose what we label as the Geo-Social Model. This experimental methodology aims at integrating recursive interactions between geological and social factors configuring landslide for more robust and inclusive analyses and interventions. It builds upon three analytical blocks or site-specific environments in constant co-determination: (1) The geology and geomorphology of the study area; (2) the built environment, encompassing infrastructural, urban, and planning conditions; and (3) the sociocultural environment, which includes community memory, risk perceptions, and territorial organizing. Our results are summarized in a geo-social map that systematizes the complex interactions between the three environments that facilitated the Quebrada de Macul flow-type landslide. While our results are specific to this event, we argue that the Geo-Social Model can be applied to other territories. In our conclusions, we suggest, first, that landslides in urban contexts are often the result of anthropogenic disruptions of natural balances and systems, often related to the lack of place-sensitive urban planning. Second, that transdisciplinary approaches are critical for sustaining robust and politically effective landslide risk prevention plans. Finally, that inter- and trans-disciplinary approaches to landslide risk prevention need to be integrated into municipal-level planning for a better understanding of-and prevention of-socio-natural hazards.
\end{abstract}

Keywords: geo-social model; landslide; transdisciplinarity; community-based approach; integrated research; human induced landslides; geo-social map

\section{Introduction}

Landslides (Landslides will be described according to the classification of Cruden, D. \& Varnes, D.J., 1996) will increase worldwide [1]. Due to growing urbanization, continuing deforestation and augmenting precipitations related to climatic pattern variability are intensifying landslide events [2-4], affecting particularly socioeconomically vulnerable exposed communities in urban areas [5-7]. In the case of Chile, mass flows constitute one of the greatest geological threats in urban areas, with considerable human losses; this has been explained in developing countries as a consequence of higher poverty rates, more corrupt governments, and weaker healthcare systems [6,8]. In particular, the Metropolitan Region-where Quebrada de Macul is located-is one of the areas with the highest periodicity of landslide events in the last 30 years [9]. In fact, from 1908 to the present there have been 12 alluvial events [9] including on of the worst national catastrophes since the 1950s: The flow of 3 May 1993 in Quebrada de Macul (henceforth QM). 
That morning, intense rainfall, high temperatures, and a zero-degrees isotherm at $2000 \mathrm{~m}$ a.s.l. combined, generating the perfect conditions for debris flow and mudflow. The result was a mass removal event of different pulses of debris and mud flow with accumulated material of $6.5 \times 10^{5}$ and $1 \times 10^{6} \mathrm{~m}^{3}$, and with a deposit thickness reaching more than $3 \mathrm{~m}$ in the axis of the stream composed of silt, sand, and blocks of up to $3 \mathrm{~m}$ in diameter, in addition to eucalyptus trunks and anthropogenic debris. It should be noted that the first flow began at 11:40 am with a debris flow of up to $1 \mathrm{~m}$ high, reaching speeds of up to $15 \mathrm{~km} / \mathrm{h}$, and $30 \mathrm{~km} / \mathrm{h}$ in the second pulse developed 10 min later, directly impacting the urban area, destroying houses, trucks, sheds, trunks, etc. The consequence was the devastation of urban areas along the ravine in the districts of La Florida and Peñalolén in the metropolitan area of Santiago (Figure 1). The disaster left 26 deaths, 8 missing, 85 injured, and more than 30,000 people affected. In addition, 307 houses were destroyed and another 5610 were severely damaged [10].

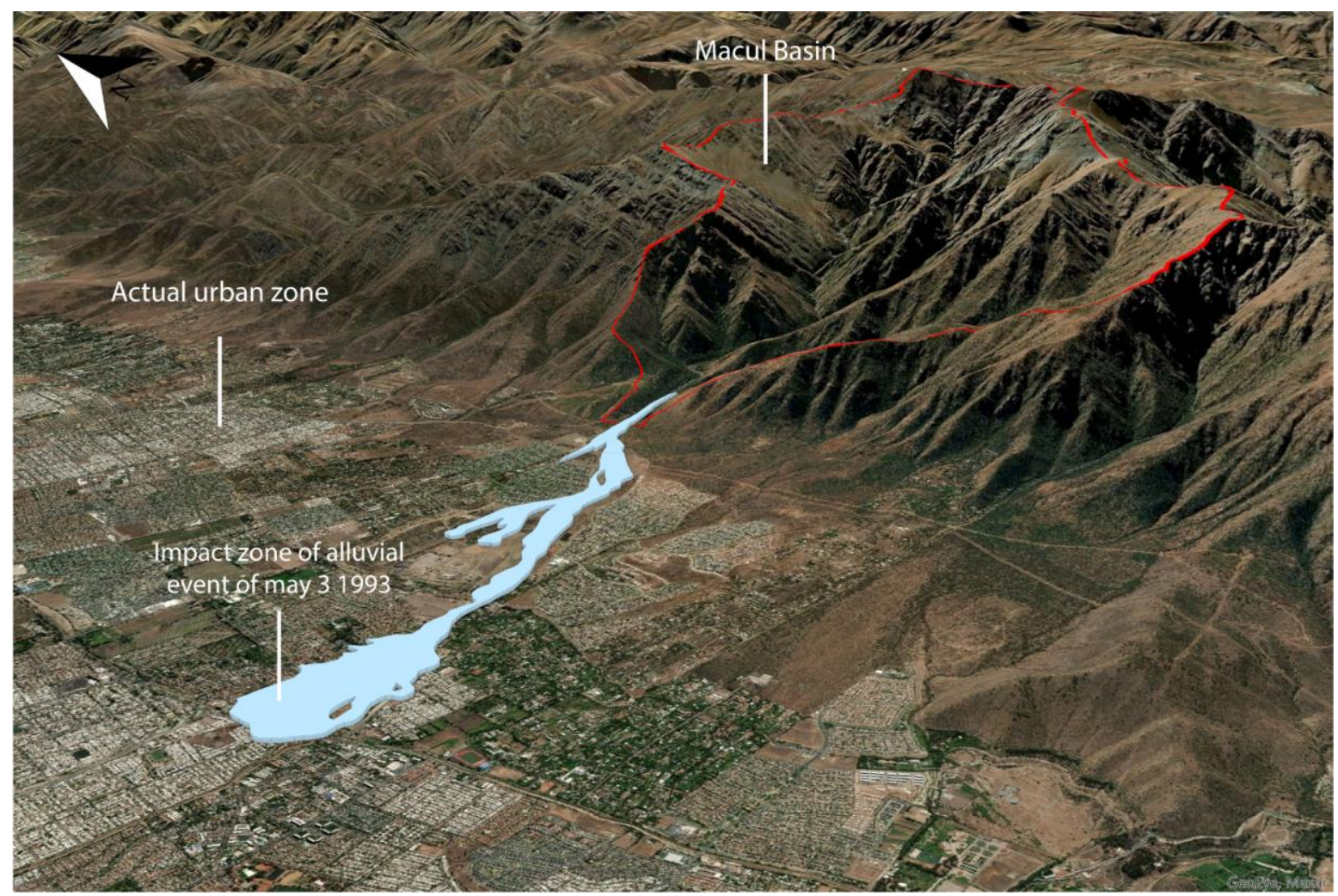

Figure 1. Macul basin (line in red) and the impact zone of the alluvial event of 3 May 1993 (area in light blue) in contrast to the present urban area.

The memory of these events is still present in the community today, standing as a major sociocultural marker in affected neighborhoods [10]. Since the catastrophe, the area has undergone intense demographic transformations, including rapid urbanization and gentrification processes [11]. This has not reduced, however, the likelihood of a similar event today. Research has confirmed that anthropogenic modifications in the basin mouth, particularly the loss of ground waterproofing due to piedmont urbanization, directly affect the quantity and speed of water flows as well as the hydraulic characteristics of mountain sediments, configuring an important source of alluvial susceptibility [12]. Additionally, the expected effect of climate change on the hydrometeorology of the area will likely mean a decrease in rainfall and flow levels, as well as an increase in annual temperatures [13-16]. This could have important effects on the occurrence of floods and flow-type landslides by contributing to the increase in the elevation of the $0{ }^{\circ} \mathrm{C}$ isotherm. Furthermore, as an 
increase in the frequency and/or intensity of warm storms is expected, these can produce runoff with high amounts of sediment in shorts periods of time.

The case of QM brings to the fore the complex interactions between hydrological, geological, infrastructural, and sociocultural processes in landslide causes and effects, particularly in the perspective of landslides prevention at the local level. It also points to the lack of integrated, transdisciplinary analyses in Chile, Latin America, and developing countries at large. Research to date has contributed to the characterization of the QM basin and its geo- and hydromorphological features [6,9,17-21], of the history-and current processes-of the area's territorial planning [22], and the social imaginaries and organization around the QM disaster $[10,23]$. These research agendas, however, have remained largely unconnected, hence blocking the articulation of integrated models for participatory landslide risk management at the local level. In turn, this lack of integration has perpetuated existent and obdurate disciplinary demarcations in landslide planning [24]. This is not uncommon in the region. There is still limited understanding about the association between geological processes and the social, economic, and cultural factors driving flow-type landslides [4]. This integration deficit is particularly acute in contexts of weak institutional structures, as in the case of Latin America, which hamper robust and effective risk reduction initiatives $[25,26]$.

This contrasts with the call made by the Agency for Integrated Risk Reduction Research and Prevention [27-31] — a call reinforced by the Sendai Framework [32] and the Global Assessment Report on Disaster Risk Reduction [33]. As it has been suggested by these calls, a critical challenge is to provide practical solutions, education, communication, and public outreach to reduce landslide disaster risk, to which end transdisciplinary involvement, knowledge co-production, and process-oriented and territorially embedded initiatives are fundamental components [24,33,34]. This implies, first and foremost, a substantive epistemological shift in the way that geohazards are understood, analyzed, and intervened. As argued by Alcántara-Ayala [24] (p. 155), "most of the work on landslides has been undertaken from a discipline-focused approach, especially in the physical, earth sciences and engineering fields. To a lesser extent, investigations have been carried out from a social science perspective, whereas Integrated Research on Landslide Disaster Risk is practically non-existing". This may be caused, as Matsura and Razak [35] (p. 5) suggest, because "hazard science is still predominantly conducted in a traditional framework of basic geosciences in which scientists do not feel the responsibility to translate knowledge into actions".

To fill this gap, in this paper we develop what we call the Geo-Social Model: a systematic attempt at integrating diverse knowledges for assessing and acting upon complex geoclimatic events. The Geo-Social Model aims at integrating geological and social analyses for flow-type landslide reduction and planning, while also incorporating local communities as fundamental scientific and political actors. Drawing on the case of QM, the Geo-Social Model therefore is, we suggest, a research device, a policy tool, and an epistemological proposition.

The reminder of the paper is organized as follows. We first describe our analytical framework and methodological approach to the QM case. Second, we apply the Geo-Social Model through a transdisciplinary approach. Third, we identify the interactions between geological, planning, and social processes and visualize them via a geo-social map. Finally, we discuss our results with the broader literature. While we apply the model to the QM case, we suggest that the Geo-Social Model-by identifying and analyzing the connections of the above-mentioned processes-offers a robust tool to (a) understand the complex phenomenology of the landslides than impact in urban zones, (b) integrate the community in disaster risk reduction initiatives, and (c) connect scientific research to policy making in diverse contexts. 


\section{Materials and Methods}

\subsection{Analytical Framework}

The analytical framework of this study is based on the category of geo-social processes, highlighting the role of transdisciplinarity as both a conceptual and methodological tool for landslide analysis and prevention.

\subsubsection{The Geo-Social Model}

In this paper, we attempt at integrating recursive interactions between geological and social factors configuring and understanding landslides-related certain characteristics. These interactions have been described independently, focusing on geology $\rightarrow$ social interactions or on social $\rightarrow$ geology interactions [36,37], seldom recognizing co-determinations (geology $\leftarrow \rightarrow$ social interactions We borrow from Clark and Yusoff [38] and their understanding of "geosocial formations" as processes in which geological events are influenced by social trajectories, just as much as social phenomena are shaped by geological conditions. This approach builds on current theorizations that have recognized the mattered condition of human and social life [39] and the urgent need to include more-than-biological elements in the explanation of social processes [40,41]. This perspective is also consistent with the ecosystem-based disaster risk reduction model [42] in as much as it also attempts at linking physical exposure to infrastructure and socio-economic resilience. Our model, however, emphasizes the relevance of geophysical conditions in the understanding of landslide-related hazards.

To operationalize our Geo-Social Model, we identify three analytical blocks or sitespecific environments in constant interaction: (1) The geological environment or the characterization of the basin, which includes the geology and geomorphology; (2) the built environment, encompassing infrastructural, urban, and planning conditions; and (3) the sociocultural environment, which includes community memories, individual and collective risk perceptions, and local organizations.

\subsubsection{Transdisciplinary Approach}

We define transdisciplinary research as iterative methods seeking the involvement of actors from outside academia into the research process in order to integrate the best available knowledge, reconcile values and preferences, as well as create ownership for problems and solution options [43]. Transdisciplinary research, in the context of landslide risk reduction, aims at combining different scientific disciplinary approaches with traditional, indigenous, and community knowledge to solve problems associated with local risk reduction programs that account for diverse spatial-temporal scales under no epistemological and methodological constraints, entitling decision and policymaking for societal benefit and territorial sustainability [24,44].

The Geo-Social Model takes an explicit transdisciplinary perspective (Figure 2). By embracing a holistic approach, the model assumes, in ontological terms, that environmental, social, and built systems are inextricably coupled. Epistemologically, it assumes that co-produced and collaborative knowledge allows for mutual learning, better account of uncertainties, and better policy decisions [45]. 


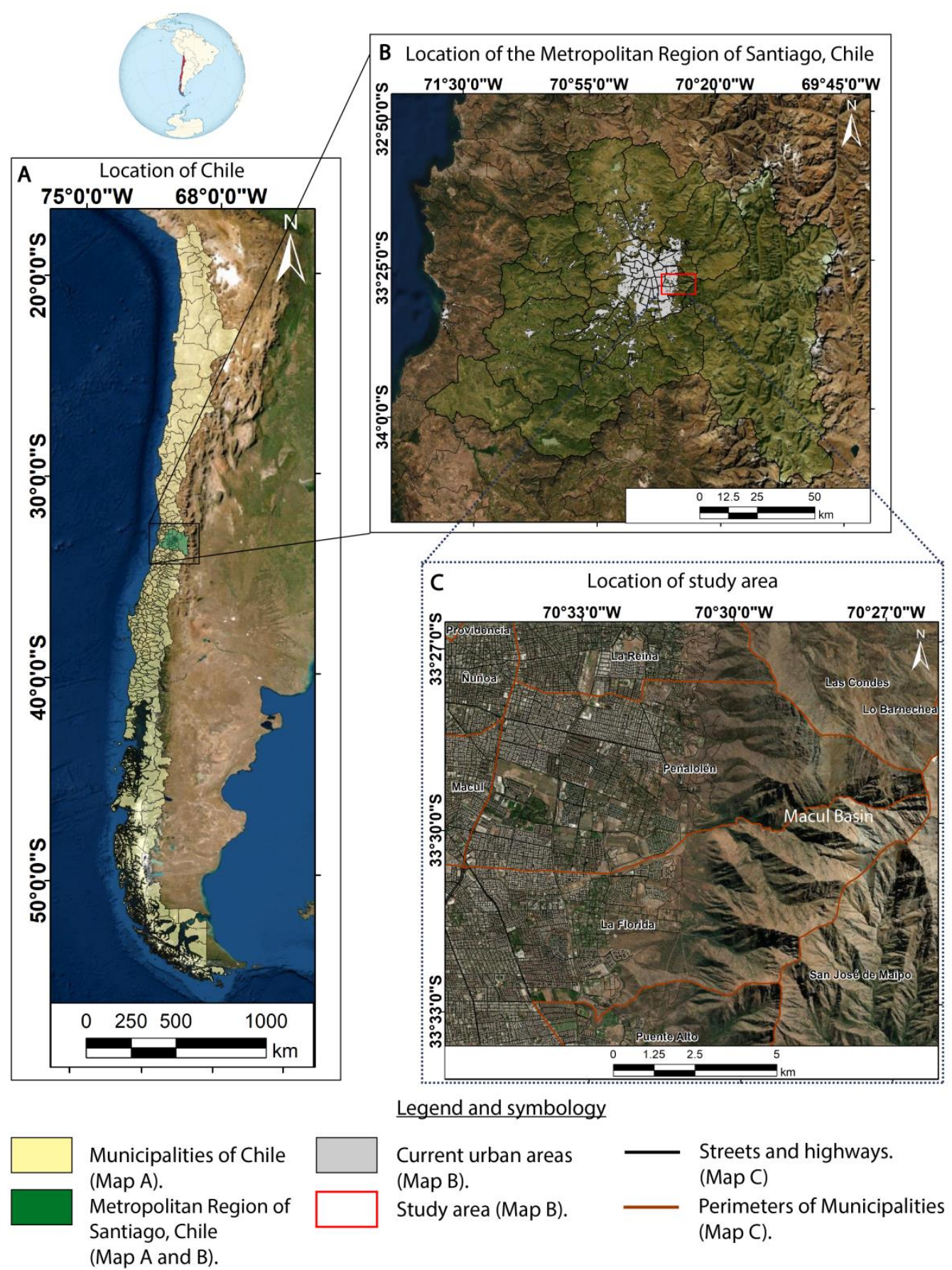

Figure 2. Location map of the Macul basin. (A) Chile location map on a national scale. (B) Location of the Metropolitan Region of Santiago, Chile. (C) Location of the study area that includes the perimeter of the municipalities of the Metropolitan Region.

\subsection{Research Site: The Macul Basin}

Macul basin (QM) is located in the central zone of Chile, in the city of Santiago of the Metropolitan Region; specifically, in the municipalities of La Florida and Peñalolén, in the western zone of the Andes Mountains and the Central Depression (between the coordinates 6,288,809-6,294,807 $\mathrm{mN}$ and 353,855-366,536 mE, respectively). Both represent cases of population and urban growth (La Florida is the fourth district with the largest population in the metropolitan region according to the 2017 CENSUS with 366,916 inhabitants while Peñalolén occupies the 13th position with 241,599 inhabitants [46]). The urban expansion 
percentage towards the piedmont for the period 1995-2016 was 7.1 in La Florida and 14.1 in Peñalolén [47] towards peripheral areas with a large presence in the piedmont area with a spatial reconfiguration given by gentrification processes [48] (Figure 3).

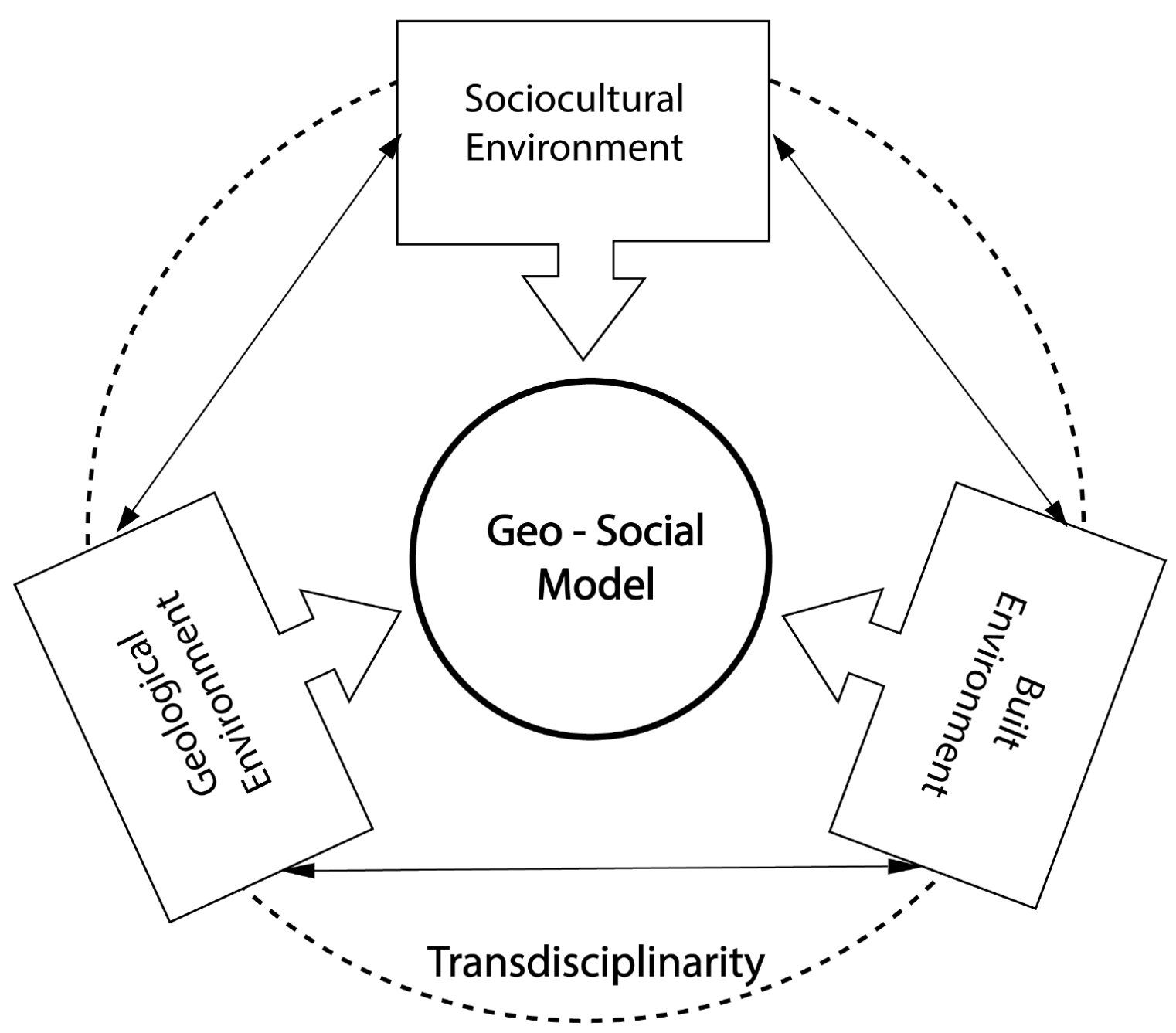

Figure 3. Geo-Social Model diagram. Source: Authors' own elaboration.

\subsection{Methodology}

We simultaneously applied disciplinary specific methods (Table 1), in-situ iterative and participatory mixed methodology in order to share findings, identify interactions, and find spaces of collaboration and co-construction of knowledge. For the last, we triangulated evidence from the three environments. In general terms, triangulation refers to the process by which multiple research strategies are brought together [49]. In this case, we carried out holistic triangulation for capturing "more complete, holistic, and contextual portrayal of the unit(s) under study" and enriching "our understanding by allowing for new or deeper dimensions to emerge" [50] (pp. 603-604). We did this through periodical meetings between the research team where evidence from each environment was shared and discussed. In order to establish transdisciplinary conceptual connections, visual aids were done through the use of diagrams and the elaboration of a geo-social map with the ArcGIS-Arc.Map 10.8, Arcgis Pro 2.6 and Illustrator v24.1 software, which synthesizes the interconnections between the results of the three environments of our Geo-Social Model. 
Table 1. Methodological synthesis.

\begin{tabular}{|c|c|c|c|}
\hline & Geological Environment & Built Environment & Socio-Cultural Environment \\
\hline Methods & $\begin{array}{l}\text { Generation of maps and } \\
\text { geological and geomorphological } \\
\text { analysis using quantitative and } \\
\text { qualitative methodologies. }\end{array}$ & $\begin{array}{l}\text { Qualitative case study approach: } \\
\text { archival research. }\end{array}$ & $\begin{array}{l}\text { Qualitative case study approach: } \\
\text { in-depth interviews, ethnographic } \\
\text { observations, and } \\
\text { participatory methods. }\end{array}$ \\
\hline Materials & $\begin{array}{l}\text { Bibliographic references, digital } \\
\text { elevation model, satellite images } \\
\text { and historical geographic maps. }\end{array}$ & $\begin{array}{l}\text { Chilean Daily Documentary Fund } \\
\text { (BN), digital map library (BN and } \\
\text { UCH) and administrative } \\
\text { documents, mass media. }\end{array}$ & $\begin{array}{l}\text { Oral testimonies, interviews, } \\
\text { observations, and photographs. }\end{array}$ \\
\hline Data Collection & $\begin{array}{l}\text { Transfer, purchase, search } \\
\text { information and images. }\end{array}$ & $\begin{array}{c}\text { Transfer and paleography of } \\
\text { archival and } \\
\text { audiovisual materials. }\end{array}$ & $\begin{array}{c}\text { Participatory observation, } \\
\text { interviews, photographic record. }\end{array}$ \\
\hline Data analysis & $\begin{array}{l}\text { Digitization of geographic } \\
\text { information, digital elevation } \\
\text { model processing and } \\
\text { photointerpretation. }\end{array}$ & $\begin{array}{l}\text { Hermeneutic and three } \\
\text { level lecture. }\end{array}$ & $\begin{array}{l}\text { Contextual data analysis and } \\
\text { three level lecture. }\end{array}$ \\
\hline \multicolumn{4}{|c|}{ In situ iterative and participatory mixed methodology } \\
\hline & eriodic meetings, eviden & ared and co-construction of know & edge. \\
\hline
\end{tabular}

For the geological environment, a geological characterization is developed, geomorphological landforms, in addition to a morphometric analysis representing the quantitative analysis of the geographical surface [51], with the aim of deepening its characterization and obtaining information on the hydrological response of the basin. All this because these factors are considered, among the most relevant in the development of flow-type landslides [52-55], which in turn are influenced by each other in different ways and degrees.

Specifically, the morphometric analysis is carried out by analyzing the basin (the mouth area is not considered since the contribution area is analyzed, which in this case is represented by the Macul basin) based on its physical parameters and its shape, from the calculation and classification of numerical values based on the work of different authors [56], in which case they include different parameters: Shape parameters, drainage network, relief, and complementary parameters. The choice of each of these parameters and the corresponding analysis is due to the type of information they provide and their usefulness for this particular area. For this purpose, Digital Elevation Model (DEM) processing was carried out using specific geoprocessing tools of ArcGis Pro v26.0.0 and ArcMap v10.8 software. The first and fundamental step is the delimitation of the area and perimeter of the Macul basin $(\mathrm{QM})$, in addition to generating the drainage network of the basin with the use of Arc Hydro Tools and Hydrology of Spatial Analyst tools, whose processing is summarized in Table 2.

Once these data were obtained, we proceeded to establish the methodology for obtaining each of the morphometric parameters mentioned above (Table 3), to subsequently obtain the results using mathematical calculation tools of ArcGis Pro v26.0.0 and ArcMap v10.8 software, and complementarity by exporting the resulting data in spreadsheets in Microsoft Excel software. It should be noted that the hypsometric curve was obtained by calculating ranges of height classes every $100 \mathrm{~m}$, in order to subsequently calculate the Relative Elevation and Relative Area of the basin. All this by means of geoprocessing Mask, Reclass, dissolve of ArcGis Pro v26.0.0 with the use of DSM of $4.3 \mathrm{~m}$ and export of data from the table of attributes to Excel spreadsheets to later generate the corresponding graph. 
Table 2. Geoprocessing of Digital Elevation Models (DEM) in ArcGis Pro v26.0.0 and ArcMap v10.8 software to obtain relief and drainage parameters such as the area and perimeter of the Macul basin, as well as the drainage network.

\begin{tabular}{|c|c|c|c|}
\hline Arc Hidro Tools-Spatian Analyst Tool & Basin & Drainage & Use \\
\hline Fill Sink & $\mathrm{x}$ & $\mathrm{x}$ & $\begin{array}{l}\text { Digital correction of errors due to image } \\
\text { resolution, obtaining more accurate elevations } \\
\text { and depressions. RASTER format. }\end{array}$ \\
\hline Flow direction & $\mathrm{x}$ & $\mathrm{x}$ & $\begin{array}{l}\text { Characterization of the flow direction. RASTER } \\
\text { format }\end{array}$ \\
\hline Flow Accumulation & $\mathrm{x}$ & $\mathrm{x}$ & $\begin{array}{l}\text { Determines in which specific area there is a } \\
\text { considerable flow accumulation. } \\
\text { RASTER format. }\end{array}$ \\
\hline Stream Definition & $\mathrm{x}$ & & \multirow{2}{*}{ Definition of drainage density. RASTER format } \\
\hline Con-mathematical conditional & & $\mathrm{x}$ & \\
\hline Stream Segmentation & $\mathrm{x}$ & & \multirow{2}{*}{$\begin{array}{l}\text { Distinguish each section of the stream based on } \\
\text { its junctions. RASTER format. }\end{array}$} \\
\hline Stream Link & & $\mathrm{x}$ & \\
\hline Stream Order & & $\mathrm{x}$ & $\begin{array}{l}\text { Assign a numerical order to the segments of a } \\
\text { RASTER representing the drainage networks } \\
\text { using Strahler's methodology. RASTER format. }\end{array}$ \\
\hline Catchment grid delineation & $\mathrm{x}$ & & $\begin{array}{l}\text { Delineation of the sub-basins in question by cells. } \\
\text { RASTER format. }\end{array}$ \\
\hline Catchment polygon processing & $x$ & & \multirow{2}{*}{$\begin{array}{l}\text { Transformation of RASTER format into } \\
\text { VECTORIAL format. }\end{array}$} \\
\hline Stream to Feature & & $\mathrm{x}$ & \\
\hline Atribute Table-Calculate Geometry & $\mathrm{x}$ & $\mathrm{x}$ & $\begin{array}{l}\text { Calculations tool on all or selected records for } \\
\text { calculate area, length, perimeter, and other. }\end{array}$ \\
\hline
\end{tabular}

In addition, a geomorphological landform map was made using a mainly qualitative methodology (with the exception of the delimitation of slopes and escarpments, which were identified from slope map from DEM and DSM) with the adaptation and modification to this particular geographic area of the methodology applied by the Colombian Geological Service or SGC [57], since its objective is the zoning of susceptibility and threat due to landforms, in addition to having a wide and successful experience in research and application in urban areas. Landforms are considered as a land surface that reflects a typical configuration of each environment, defined in its development by a particular process with morphological characteristics, as well as some intrinsic properties (lithology, fracturing, weathering, among others), which are combined in a physical space and determine the generation of a mass movement [57]. This was done through a bibliographic study, identification, and mapping of existing landforms. Specifically, DEM and DSM (Table 4) were used to delimit slopes and escarpments, as well as to identify riverbeds and to understand the morphology of the basin relief. In addition, the geological cartography generated was used, as well as photointerpretation at scales ranging from 1:1:1000 to 1:20,000 with the use of high-resolution satellite images. In its development, substantial surface changes were identified in the mouth area, due to anthropogenic influence, and therefore, multitemporal mapping is incorporated through Google Earth Pro v7.3.3.7786 images (Table 4) and the use of historical maps for landform delimitation of urban areas and agricultural and land leveling surfaces on alluvial fans, identifying their evolution over time and advancing in the understanding of how they influence in triggering socio-natural disasters. 
Table 3. Definition and methodology for obtaining morphometric parameters of the Macul basin.

\begin{tabular}{|c|c|c|}
\hline \multicolumn{3}{|c|}{ Form Parameters } \\
\hline Name & Equation or Method & Description \\
\hline Basin Area $(A)\left[\mathrm{km}^{2}\right]$ & \multirow{4}{*}{ Geographic information system (GIS) } & $\begin{array}{l}\text { A measure of the surface area of a surface of a basin, } \\
\text { defined as the orthogonal projection of the entire } \\
\text { drainage area of a runoff system directed directly or } \\
\text { indirectly to the same natural channel (López, 2008). }\end{array}$ \\
\hline Basin Perimeter $(\mathrm{P})[\mathrm{km}]$ & & $\begin{array}{l}\text { It is defined as the measurement of the watershed } \\
\text { envelope line, by the topographic watershed (Gaspari, } \\
\text { 2012). }\end{array}$ \\
\hline Axial Length $\left(\mathrm{A}_{1}\right)[\mathrm{km}]$ & & $\begin{array}{l}\text { Distance in a straight line between the mouth and the } \\
\text { farthest point on the perimeter (P) of the basin, which } \\
\text { in some cases coincides with the length of the main } \\
\text { course (Gaspari, 2012) }\end{array}$ \\
\hline $\begin{array}{l}\text { Length of the main channel (Lc) } \\
{[\mathrm{km}]}\end{array}$ & & $\begin{array}{l}\text { Represents the length of the channel over its entire } \\
\text { length }(\mathrm{km}) \text {, including all the sinuosity of the channel. }\end{array}$ \\
\hline Form Factor (F) (Horton, 1932) & $\mathrm{F}=\frac{A\left(k m^{2}\right)}{(L c)^{2}(k m)}$ & $\begin{array}{l}\text { It is defined as the ratio between the area }(A) \text { and the } \\
\text { length of the drainage basin }\left(L_{c}\right) \text {. }\end{array}$ \\
\hline $\begin{array}{l}\text { Compactness Factor }\left(\mathrm{K}_{\mathrm{c}}\right) \\
\text { (Gravelius, 1914) }\end{array}$ & $K_{c}=0.28 \times\left(\frac{P(k m)}{\sqrt{A\left(\mathrm{~km}^{2}\right)}}\right)$ & $\begin{array}{l}\text { This factor is the oldest one, expresses the relationship } \\
\text { between the perimeter of the drainage basin and that } \\
\text { of a circle of equal area (equivalent circle); thus, } \\
\text { the higher the coefficient, the more distant the shape of } \\
\text { the basin will be with respect to the circle. P represents } \\
\text { the perimeter }(\mathrm{km}) \text { and A the area }\left(\mathrm{km}^{2}\right) \text { of the Macul } \\
\text { basin. }\end{array}$ \\
\hline
\end{tabular}

\section{Drainage System Parameters}

\begin{tabular}{ccc}
\hline Name & Equation or Method & Description \\
\hline
\end{tabular}

Horton (1945) suggests a hierarchization of streams according to order number as a measure of the

Drainage order (n)

(Strahler, 1964)

Geographic information system (GIS)

branching of the main channel in a basin. This system is dimensionless and was later improved and slightly modified by Strahler (1964), indicating that a stream may have one or more segments.

It is the ratio between the total number of drains of a certain order $\left(n_{i}\right)$ and the total number of drains of the next higher order $\left(\mathrm{n}_{\mathrm{i}+1}\right)$.

$\begin{aligned} & \text { Bifurcation ratio }\left(\mathrm{B}_{\mathrm{r}}\right) \\ & \text { (Strahler, 1964) }\end{aligned} \quad B_{r}=\frac{n_{i}}{n_{i+1}}$

$$
L_{r}=\frac{L_{i}(k m)}{L_{i-1}(k m)}
$$

The ratio of the average length of a certain order of drainage to the average length $\left(\mathrm{L}_{\mathrm{i}}\right)$ of the drainages of immediately lower order $\left(\mathrm{L}_{\mathrm{i}-1}\right)$.

Quotient between the total length of the channels of all

Density of the drainage network

(Dd) (Horton, 1945) $[1 / \mathrm{km}] \quad D d=\frac{\Sigma L_{i}(\mathrm{~km})}{A\left(\mathrm{~km}^{2}\right)}$ the orders that make up the river system of the basin $\left(\sum \mathrm{L}_{\mathrm{i}}\right)$ and the total area of the basin $(\mathrm{A})$.

It is defined as the quotient between the total number

Drainage Frequency (F)

(Ordoñez, 2011 in Garay \&

Agüero, 2018) $\left[1 / \mathrm{km}^{2}\right]$.

$$
F=\frac{n_{t}}{A\left(k m^{2}\right)}
$$

of river courses $\left(\mathrm{n}_{\mathrm{t}}\right)$ and the area of the basin $\left(\mathrm{km}^{2}\right)$. When obtained, it establishes the greater or lesser possibility that any drop of water will find a channel in a greater or lesser time.

Represents the highest drainage order, obtained using Strahler's (1964) drainage order methodology. 
Table 3. Cont.

\begin{tabular}{|c|c|c|}
\hline \multicolumn{3}{|c|}{ Relief Parameters } \\
\hline Name & Equation or Method & Description \\
\hline $\begin{array}{l}\text { Absolute elevation difference } \\
\text { (H) [m a.s.l.] }\end{array}$ & $H(m$ a.s.l $)=(H M-H m) \quad(m$ a.s.l. $)$ & $\begin{array}{l}\text { Corresponds to the difference between the maximum } \\
\text { elevation (HM) and the minimum elevation (Hm), } \\
\text { measured in meters above sea level (m a.s.l.). }\end{array}$ \\
\hline $\begin{array}{l}\text { Average slope of the basin } \\
(\mathrm{Sm})[\%]\end{array}$ & Geographic information system (GIS) & $\begin{array}{l}\text { The average slope of a watershed is directly related to } \\
\text { the degradation process to which a watershed is } \\
\text { subjected (López Cadenas de Llano, 1998). }\end{array}$ \\
\hline $\begin{array}{l}\text { Hypsometric curve } \\
\text { (Strahler, 1964) }\end{array}$ & $\begin{array}{l}\text { Geographic information system (GIS) } \\
\text { and mathematical calculations by } \\
\text { calculating relative elevation and } \\
\text { relative area, and then applying the } \\
\text { results to a graph }\end{array}$ & $\begin{array}{l}\text { The hypsometric curve suggested by Langbein et al. } \\
\text { (1947) graphically represents the elevations of the } \\
\text { terrain as a function of the corresponding surfaces. } \\
\text { According to Strahler (1964), the importance of this } \\
\text { relationship lies in the fact that it is an indicator of the } \\
\text { state of dynamic equilibrium of the basin, so the basin } \\
\text { can be in a state of youth (disequilibrium), in a state of } \\
\text { old age (equilibrium) or at intermediate levels. }\end{array}$ \\
\hline
\end{tabular}

\section{Complementary Parameters}

\begin{tabular}{|c|c|c|}
\hline Name & Equation or Method & Description \\
\hline $\begin{array}{l}\text { Torrentiality coefficient }\left(\mathrm{T}_{\mathrm{c}}\right) \\
\text { (López and Romero, } 1987) \\
\left(1 / \mathrm{km}^{2}\right)\end{array}$ & $T_{c}=\frac{n_{1}}{A\left(\mathrm{~km}^{2}\right)}$ & $\begin{array}{l}\text { Index that measures the degree of torrentiality of the } \\
\text { basin, by means of the ratio of the number of } \\
\text { drainages of order } 1\left(n_{1}\right) \text { with respect to the total area } \\
\text { of the basin }(A) \text {. }\end{array}$ \\
\hline $\begin{array}{l}\text { Basin Efficiency Index }\left(I_{e}\right) \\
\text { (Aracena, 1993) }\end{array}$ & $\begin{array}{l}I_{e}=\left(D d\left(\frac{1}{k m}\right) \times 0.3\right)+(J \times 0.3)+ \\
\left(A\left(k^{2}\right) \times 0.3\right)+(S m(\%) \times 0.1)\end{array}$ & $\begin{array}{l}\text { Relationship between drainage density }(\mathrm{Dd}) \text {, } \\
\text { watershed drainage hierarchy }(\mathrm{J}) \text {, watershed area }(\mathrm{A}) \\
\text { and average slope }(\mathrm{Sm}) \text {. This value relates the } \\
\text { characteristics of the basin in terms of efficiency or } \\
\text { productivity for the triggering of debris flow or } \\
\text { alluvium processes. }\end{array}$ \\
\hline $\begin{array}{l}\text { Potentiality index }\left(\mathrm{P}_{\mathrm{i}}\right) \\
\text { (Börgel, 1978) }\end{array}$ & $P_{i}=\frac{\left(D d\left(\frac{1}{k m}\right)+F\left(\frac{1}{k m^{2}}\right)+J\right)}{A\left(k m^{2}\right)}$ & $\begin{array}{l}\text { It determines the location of erosion and accumulation } \\
\text { zones in a watershed; its determination is important. } \\
\text { A high } P_{I} \text { value will reveal that in a specific } \\
\text { hydrological basin there is accumulation of debris, } \\
\text { which could be transported if high precipitation } \\
\text { occurs, as to generate an alluvial event (Arcadis, 2008). }\end{array}$ \\
\hline $\begin{array}{l}\text { Storage Coefficient }\left(\mathrm{S}_{\mathrm{c}}\right) \text { (Garay } \\
\& \text { Agüero, 2018) }\end{array}$ & $S c=\frac{R_{l}}{R_{b}}$ & $\begin{array}{l}\text { It allows evaluating the storage capacity of the basin } \\
\text { during rainfall floods, through the relationship } \\
\text { between the Logitude Ratio }\left(R_{1}\right) \text { and the Bifurcation } \\
\text { Ratio }\left(R_{b}\right) \text {. If the storage coefficient is high, there is a } \\
\text { lower drainage density, which implies a lower amount } \\
\text { of water effectively available to runoff on the surface, } \\
\text { as a result of infiltration. }\end{array}$ \\
\hline
\end{tabular}

On the other hand, the geological characterization allows determining the type of deposit present in the basin, which conditions certain characteristics in its hydrological behavior, considering that deposits with high permeability tend to be mobilized by easy infiltration, these being generally of alluvial, colluvial, and volcanoclastic deposits, among others [58]. For this, an identification, mapping, and description of the consolidated and unconsolidated geological units of the Macul basin (QM) was carried out by collecting, digitizing, and using bibliographic information $[6,9,21,59,60]$ in conjunction with photointerpretation of the units that make up the study area based on a multiscale methodology from 1:1000 to 1:20,000 with the use of high-resolution satellite images (Table 4) with the use of ArcGis Pro v26.0.0 software. Emphasis was given to unconsolidated geological units, such as alluvial and colluvial deposits, among others, due to their preponderance to be transported by flow-type landslides. Finally, the deposit area of the mouth zone 
corresponding to the alluvial event of 1993 was digitally zoned by georeferencing impact maps from official geological reports of the National Service of Geology and Mining [54] (SERNAGEOMIN-Naranjo \& Varela, 1993), which contain empirical field data and represent accurate data of the most important alluvial event recorded in that area.

Table 4. Description of the basic inputs used for the development of the analysis and characterization of the geological environment.

\begin{tabular}{|c|c|c|c|c|c|c|}
\hline $\mathbf{N}^{\circ}$ & Image & Year & Resolution & DATUM & Satellite (s) & Utilization \\
\hline 1 & $\begin{array}{l}\text { Base Map } \\
\text { (satelital) }\end{array}$ & 2017-2019 & $\begin{array}{c}0.31 \mathrm{~m} \times 0.31 \mathrm{~m} \\
0.46 \mathrm{~m} \times 0.46 \mathrm{~m} \\
0.5 \mathrm{~m} \times 0.5 \mathrm{~m}\end{array}$ & WGS-1984 & $\begin{array}{l}\text { Esri. Maxar. GeoEye. } \\
\text { Earthstar Geographics. } \\
\text { CNES/Airbus DS. } \\
\text { USDA. USGS. AeroGRID. } \\
\text { IGN. and the GIS User } \\
\text { Community }\end{array}$ & \multirow[t]{3}{*}{ Mapping base } \\
\hline 2 & Image & 1993 & - & $\begin{array}{l}\text { Georeferencing } \\
\text { WGS-1984 }\end{array}$ & Google Earth Pro & \\
\hline 3 & Historical map & 1861 & - & $\begin{array}{l}\text { Georeferencing } \\
\text { WGS-1984 }\end{array}$ & - & \\
\hline 4 & $\begin{array}{c}\text { Digital Surface } \\
\text { Model (DSM) }\end{array}$ & - & $4.3 \mathrm{~m} \times 4.3 \mathrm{~m}$ & WGS-1984 & $\begin{array}{c}\text { Acquired by the } \\
\text { Research Center for } \\
\text { Integrated Disaster Risk } \\
\text { Management (CIGIDEN) }\end{array}$ & \multirow{3}{*}{$\begin{array}{l}\text { Morphometric } \\
\text { and } \\
\text { morphological } \\
\text { analysis }\end{array}$} \\
\hline 5 & $\begin{array}{c}\text { Digital } \\
\text { Elevation } \\
\text { Model (DEM) }\end{array}$ & - & $12.5 \mathrm{~m} \times 12.5 \mathrm{~m}$ & WGS-1984 & \multirow{2}{*}{$\begin{array}{l}\text { National Aeronautics } \\
\text { and Space } \\
\text { Administration (NASA) }\end{array}$} & \\
\hline 6 & $\begin{array}{c}\text { Digital } \\
\text { Elevation } \\
\text { Model SRTM } \\
\text { (DEM) }\end{array}$ & - & $30 \mathrm{~m} \times 30 \mathrm{~m}$ & WGS-1984 & & \\
\hline
\end{tabular}

To account for the built and socio-cultural environment, we applied a qualitative case study approach. This method allowed an in-depth and empirical examination of the alluvial phenomenon in the context of the community's daily lives and memories. Specifically, the case study approach responds to a delimited case in which there is little clarity of the relationships between a specific phenomenon and its context [61] and involves the exploration of it over time through the collection of detailed data and the use of multiple sources of information $[62,63]$.

For the built environment we used archival research, which consists in the analysis of historical documentation from public and private archives. Data collection was done through reviews and transcriptions of written press from the Chilean Daily Documentary Fund of the National Library of Chile, its digital map library, and the map library of the School of Architecture and Urban Planning at Universidad de Chile, a palaeography of colonial maps was done. Administrative documents from the Ministry of Public Works, Directorate of Hydraulic Works, and the corresponding municipalities were also compiled and analyzed. Finally, documents and photographs from personal archives of survivors were digitized, together with the audiovisual and written material from mass media social networks that recorded the 1993 event and its subsequent commemorations. Data analysis was carried out applying a hermeneutic and three-level lecture.

For the socio-cultural environment we followed the same method via in-depth interviews, ethnographic observations, and participatory methods. Data collection was extensive [62] using participatory observation techniques, interviews, and photographical register. The participatory methodology consisted of the research team's engagement in activities carried out by local organizations and field visits made between July 2019 and March 2020; both were accompanied by photographic records and observation notes [64]. In-depth interviews were conducted through a selective sampling of key actors who sur- 
vived the alluvium $(\mathrm{N}=10)$, applying a standard semi-structured interview and contextual (non-cross-sectional) data analyses at three levels: Literal, interpretative, and reflective [65] following a general inductive approach that considered the emergence of conceptual categories and themes from the data.

\section{Results}

The results given by the Geo-Social Model are synthesized in the following diagram (Figure 4) showing the principal characteristics of each environment. To account for them we first describe and analyze the evidence of each. Secondly, we make their interconnections visible through a geo-social map.

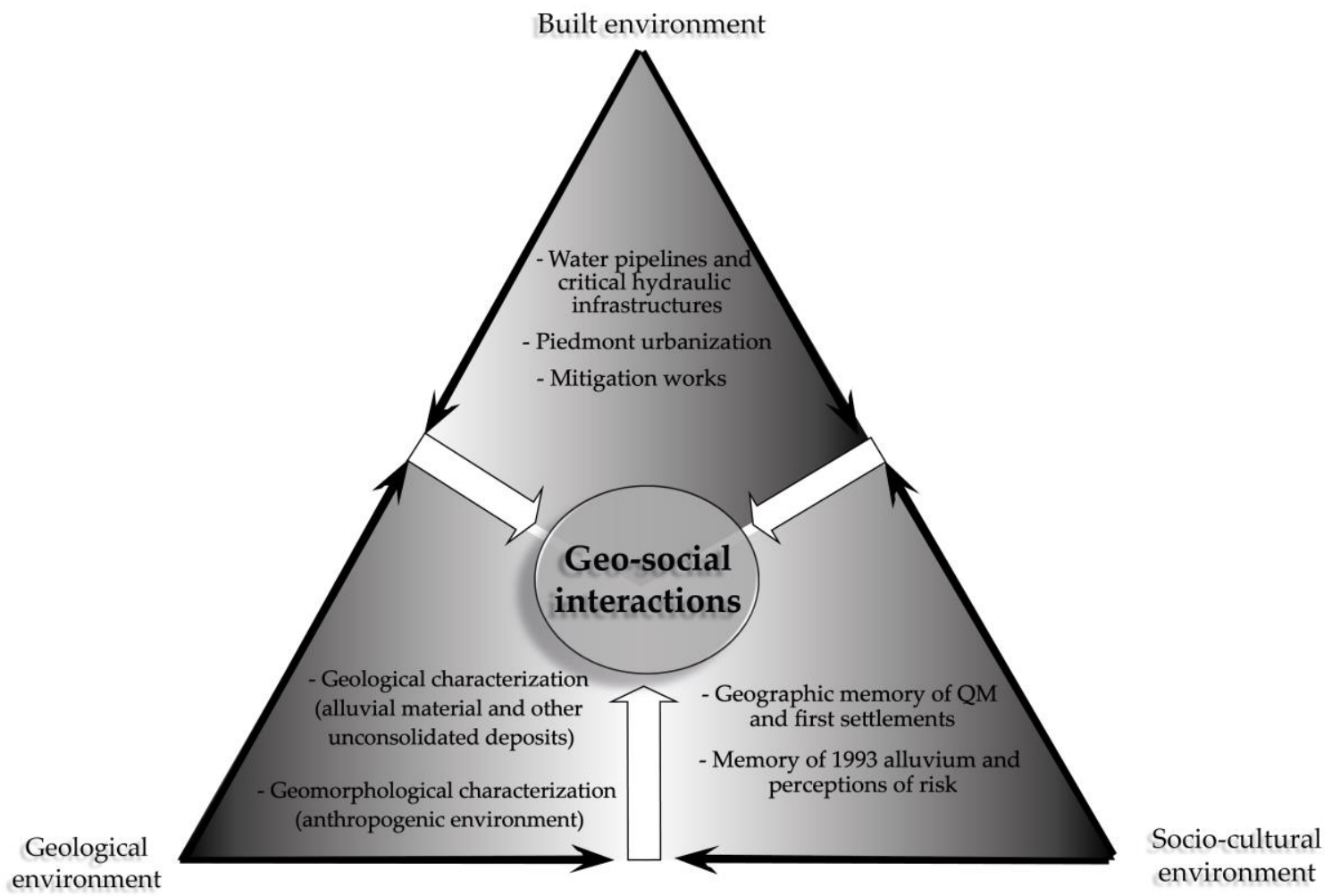

Figure 4. Results synthesis diagram.

\subsection{Geological Environment}

Characterization of the Macul Basin (QM) — Geology and Geomorphology

Based on historical alluvial events, it has been determined in the case of Santiago that, when flows develop, they usually directly impact the urban areas of the mountain foothills. However, the origin of these alluvial phenomena is not located in these particular areas; on the contrary, they originate in the so-called basins (water basins) located in this case in the western zone of the Andes, whose type of flow will depend on certain conditioning factors such as geological and geomorphological factors, among others. That is why a characterization of the basin allows progress in the understanding of these phenomena, and in turn, allows providing relevant information to the population and public entities.

The geomorphological characterization using landforms resulted in the identification and zoning of 18 types, representing denudational, structural, fluvial, and alluvial geomorphological environments and anthropogenic environments (Table 5). These landforms represent surface forms with their own distinctive characteristics of the basin, among them the Sos structural mountain range, which is characterized by the great structural influence of the Andes mountain range translated into topographic prominences of mountainous and elongated morphology with steep to abrupt slopes (Sesso and Seslso), which provide direct 
runoff in addition to high flow velocities and possibly dragging of material. In addition, Sos includes a significant number of landforms with denudational and fluvial and alluvial environments (Dlcdra, Dus, Dflc, Duf, Fffp, Frt and Fac), which are prone to be affected and contribute to debris flow towards low slope areas, which are characterized by an important anthropogenic influence, represented in this case by the settlement of urban constructions on the alluvial fans of the mouth area (Au-Faf). This is quite relevant, taking into consideration that the alluvial fans (Faf) indicate historical and/or recent discharges of alluvial material, therefore they are indicators of areas of susceptibility to the impact of this type of phenomena; however, it is highly populated. The results of multitemporal landform analysis (Figures 5 and 6), allowed us to identify its evolution in terms of influence and modification of the surface of this particular area, resulting in an initial tendency from 1881 to settlement in areas relatively far from the apex of the outfall area, even with a low percentage of $\mathrm{Au}$ areal. This is quite different from the current scenario, which resulted in a strong tendency to an increase of Au and Aatg settled in Faff, towards areas increasingly closer to the Macul basin (apex of the mouth area), some of them even being located near Aac (Figure 6), this being coherent based on records of urban expansion in the foothills of the Cordillera (Section 3.3.2).

Table 5. Result of the geomorphological analysis through the identification and characterization of landforms. The results of these are stipulated, in addition to the establishment of the definition and characteristics of each one of them.

\begin{tabular}{|c|c|c|c|c|}
\hline $\mathbf{N}^{\circ}$ & $\begin{array}{l}\text { Geomorphological } \\
\text { Environment }\end{array}$ & Name of Landform & Code & Description \\
\hline 1 & \multirow{4}{*}{$\begin{array}{l}\text { Denudational } \\
\text { Environment }\end{array}$} & $\begin{array}{l}\text { Escarpments or } \\
\text { slide slopes }\end{array}$ & Dess & $\begin{array}{l}\text { Surfaces or planes of variable dimensions, } \\
\text { usually very steep and with undulating } \\
\text { morphology, which have been exposed due to } \\
\text { landslides of rocks or rotational or translational } \\
\text { soils. (adapted from SGC, 2012) }\end{array}$ \\
\hline 2 & & $\begin{array}{l}\text { Lobe or cone of } \\
\text { debris or rock } \\
\text { avalanches }\end{array}$ & Dlcdra & $\begin{array}{l}\text { Lobe or fan-shaped structure with a long, convex } \\
\text { length and steep natural slopes. Its origin is } \\
\text { related to non-channeled avalanches induced by } \\
\text { gravitational processes, which may be intensified } \\
\text { by seismic events or heavy rains. (adapted from } \\
\text { SGC, 2012). }\end{array}$ \\
\hline 3 & & $\begin{array}{l}\text { Undifferentiated } \\
\text { slide lobe or cone }\end{array}$ & Dus & $\begin{array}{l}\text { Cone or lobe-shaped structure with a low and } \\
\text { gently undulating morphology. Its origin is } \\
\text { related to the accumulation of materials of very } \\
\text { diverse origin and granulometry, as well as to } \\
\text { mass movements with the capacity to remove } \\
\text { very heterogeneous materials, which slide along a } \\
\text { relatively planar or furrow-shaped fault surface. }\end{array}$ \\
\hline 4 & & Flow lobe or cone & Dflc & $\begin{array}{l}\text { Lobe- or fan-shaped structure with a terraced or } \\
\text { locally terraced, hilly morphology, with very } \\
\text { variable lengths ranging from short to extremely } \\
\text { long. Its origin is related to channeled } \\
\text { fluvio-torrential events or to the transport of } \\
\text { materials resulting from soil saturation. } \\
\text { Its deposit could be constituted by angular to } \\
\text { subrounded blocks embedded in a fine or } \\
\text { medium-sized matrix. (adapted from SGC, 2012). }\end{array}$ \\
\hline
\end{tabular}


Table 5. Cont.

\begin{tabular}{|c|c|c|c|c|}
\hline $\mathbf{N}^{\circ}$ & $\begin{array}{c}\text { Geomorphological } \\
\text { Environment }\end{array}$ & Name of Landform & Code & Description \\
\hline 5 & & $\begin{array}{l}\text { Undifferentiated } \\
\text { flow lobe or cone }\end{array}$ & Duf & $\begin{array}{l}\text { A lobe or fan-shaped structure with a convex, } \\
\text { convex, lobed morphology, with a very long and } \\
\text { abrupt length. Its origin is related to torrential } \\
\text { avalanches possibly induced by seismic events or } \\
\text { torrential rains capable of removing very } \\
\text { heterogeneous materials. Its deposit could be } \\
\text { constituted by angular to subrounded rocky } \\
\text { blocks of diverse origin and granulometry } \\
\text { embedded in a clayey sandy matrix and by the } \\
\text { accumulation of blocks at the wave front. } \\
\text { (adapted from SGC, 2012). }\end{array}$ \\
\hline
\end{tabular}

Cone-shaped surface, with concave to convex slopes of flat, terraced morphology. Its origin is related to radial torrential and fluvial accumulation, where a stream flows into a flat

6
Alluvial or fluvial fan Faf area. The alluvial deposits are deposited radially from the apex of the fan located at the outlet of the stream from the mountains. The channels flow cutting the fan, being deeper at the fan apex and shallower as they move away from it (adapted from SGC, 2012).

Lobe-shaped surface, with a flat, terraced morphology. Its origin is related to the alluvial

Alluvial or fluvial fan of 1993

Faf 1993 torrential accumulation in the alluvial event of 1993 , in a radial form, where a stream flows into a flat area corresponding to urbanized zones. (adapted from SGC, 2012).

Irregularly shaped channel excavated by erosion of perennial or seasonal streams, within rock massifs and alluvial or fluvial sediments.

Alluvial or fluvial channel

Fac Depending on the amount of sediment load, slope and flow, they can form varied systems (adapted from SGC, 2012).

Flat, low to undulating morphology surface, eventually floodable. It is located bordering alluvial river channels. It includes the minor fluvial planes in "V" shapes, where the fluvial Flat or flood plain Fffp currents tend to join with their tributaries to form the main channel. Its deposits may be constituted by fine sediments, originated during fluvial flooding events (adapted from SGC, 2012).

Elongated, flat to gently undulating surfaces, modeled on fluvial sediments, bounded by escarpments of different heights along a stream bed. Its origin is related to processes of erosion and fluvial accumulation within old flood plains. Their deposits could be made up of gravels, silts and clays, with a decrease in size as they move away from the riverbed (adapted from SGC, 2012). 
Table 5. Cont

\begin{tabular}{|c|c|c|c|c|}
\hline $\mathbf{N}^{\circ}$ & $\begin{array}{l}\text { Geomorphological } \\
\text { Environment }\end{array}$ & Name of Landform & Code & Description \\
\hline 11 & & $\begin{array}{l}\text { Erosive scarps of } \\
\text { structural origin }\end{array}$ & Sesso & $\begin{array}{l}\text { Elongated, flat to gently undulating surfaces, } \\
\text { modeled on fluvial sediments, bounded by } \\
\text { escarpments of different heights along a stream } \\
\text { channel. Their origin is related to fluvial erosion } \\
\text { and accumulation processes within ancient flood } \\
\text { plains. Their deposits could be made up of } \\
\text { gravels, silts and clays, decreasing in size as they } \\
\text { move away from the riverbed }\left(>55^{\circ}\right) \text { (adapted } \\
\text { from SGC, } 2012 \text { and Sánchez, 2014). }\end{array}$ \\
\hline 12 & Structural environment & $\begin{array}{l}\text { Erosive slopes of } \\
\text { structural origin }\end{array}$ & Seslso & $\begin{array}{l}\text { Sloping surfaces, with regular to irregular } \\
\text { morphology, where tectono-structural and } \\
\text { erosive processes prevail, and may be defined by } \\
\text { planes (strata, foliation, diaclasis, among others), } \\
\text { either arranged in the opposite direction to the } \\
\text { slope of the terrain (counter-slope) or in favor of } \\
\text { the slope of the terrain (structural slope). } \\
\text { They can be long to extremely long, whose slopes, } \\
\text { being of structural origin, are around steep slopes } \\
\left(45-54.9^{\circ}\right) \text { (adapted from SGC, } 2012 \text { and } \\
\text { Sánchez, 2014). }\end{array}$ \\
\hline 13 & & $\begin{array}{l}\text { Structural origin } \\
\text { saws }\end{array}$ & Sos & $\begin{array}{l}\text { Topographic promontories of mountainous and } \\
\text { elongated morphology with long to extremely } \\
\text { long slopes, mostly straight, with very steep to } \\
\text { abrupt slopes, where tectono-structural processes } \\
\text { and erosion or accentuated mass movements } \\
\text { prevail. It corresponds to the Andes Mountain } \\
\text { Range (adapted from SGC, 2012). }\end{array}$ \\
\hline 14 & & Artificial channel & Aac & $\begin{array}{l}\text { Channels constructed for dredging, rectification } \\
\text { of channels for channeling the Macul stream in } \\
\text { urban areas and locally for water supply } \\
\text { (adapted from SGC, 2012). }\end{array}$ \\
\hline 15 & & Slagheaps & Asl & $\begin{array}{l}\text { All types of solid waste resulting from } \\
\text { demolition, repair of buildings or construction of } \\
\text { civil works, i.e., the leftovers of any action carried } \\
\text { out on urban structures. In which the disposal } \\
\text { process can be technical or non-technical } \\
\text { (adapted from SGC, 2012) }\end{array}$ \\
\hline 16 & $\begin{array}{l}\text { Anthropogenic } \\
\text { environment }\end{array}$ & $\begin{array}{l}\text { Mining or } \\
\text { extraction of } \\
\text { alluvial sediments }\end{array}$ & Aemc & $\begin{array}{l}\text { These are extensive areas dedicated to the } \\
\text { open-pit extraction of materials and minerals, } \\
\text { whose extraction process is carried out on the } \\
\text { surface of the land. It includes terraces made on } \\
\text { hillsides for the extraction of construction } \\
\text { materials such as blocks, sand and gravel, coming } \\
\text { from alluvial fans, where it is also settled } \\
\text { (adapted from SGC, 2012). }\end{array}$ \\
\hline 17 & & $\begin{array}{l}\text { Agricultural } \\
\text { terraces or } \\
\text { grading areas }\end{array}$ & Aatg & $\begin{array}{l}\text { Terraces built by man on alluvial fans of the } \\
\text { Macul basin, using the same land of the place, for } \\
\text { agricultural activities. The terraces are made with } \\
\text { the aim that the included soils used with } \\
\text { agricultural crops. In a similar way, grading } \\
\text { surfaces are made in order to adapt the land for } \\
\text { construction or for the purpose of stabilizing } \\
\text { slopes (adapted from SGC, 2012). }\end{array}$ \\
\hline
\end{tabular}


Table 5. Cont.

\begin{tabular}{|c|c|c|c|c|}
\hline $\mathbf{N}^{\circ}$ & $\begin{array}{l}\text { Geomorphological } \\
\text { Environment }\end{array}$ & Name of Landform & Code & Description \\
\hline 18 & & Urbanized areas & $\mathrm{Au}$ & $\begin{array}{l}\text { Modified and modeled surface on alluvial fans } \\
\text { for the purpose of building housing and } \\
\text { infrastructure necessary for the population. } \\
\text { They are made up of materials of variable origin } \\
\text { and are built in flat areas with large areas covered } \\
\text { with concrete, and to a lesser extent with green } \\
\text { areas and areas devoid of vegetation. }\end{array}$ \\
\hline
\end{tabular}

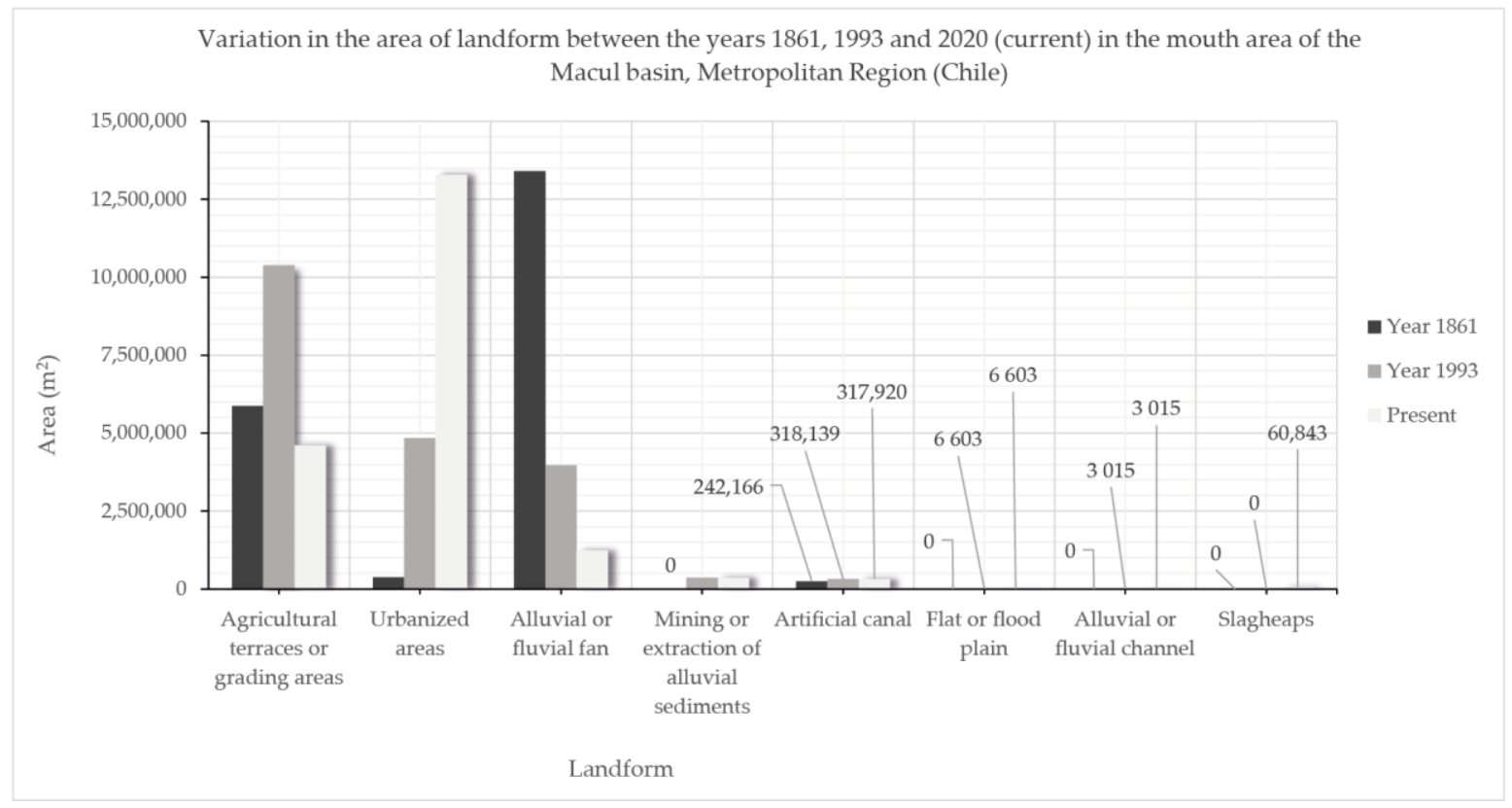

Figure 5. Trend of areal variation of landform with multitemporal area at the mouth of the Macul basin.

Regarding the morphometric analysis, this is made up of the parameters of Shape, Drainage System, Relief, and Complementary. All this with the objective of inferring the hydrometeorological response of the Macul basin:

Shape parameters (Table 6): A basin with an area (A) of rainwater catchment of $23.5 \mathrm{~km}^{2}$ is obtained, representing the second largest area basin in the entire foothills of the Santiago mountain range, only surpassed by the San Ramón basin (Figure 7 and Appendix A). According to the Horton Form factor (F) classification [66] and the compactness factor classification (Kc) [67], they indicate that the Macul basin (QM) is a widened basin with a short main channel and an intermediate shape between round-oval and an oblong basin, with the consequence of having a tendency to concentrate the runoff of an intense rainfall; easily forming large flow because the relative distances of the points of the divide with respect to a central one does not present major differences and the time of concentration becomes shorter. 


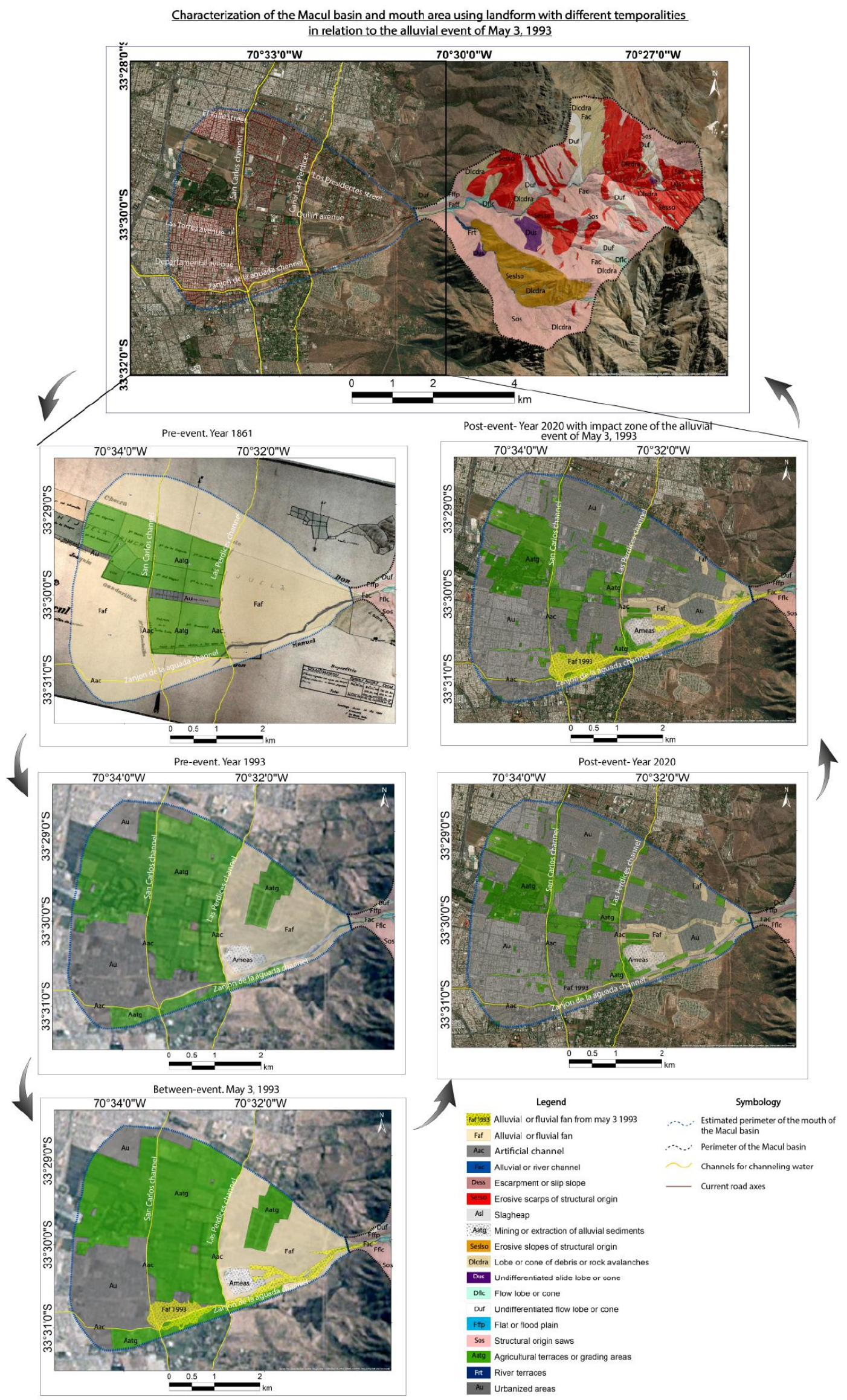

Figure 6. Multitemporal map of landform of the total Macul basin. The black arrow indicates changes in temporality. 
Table 6. Results of the Form Parameters for the Macul basin.

\begin{tabular}{lc}
\hline \multicolumn{1}{c}{ Name } & Form Parameters \\
\hline \multicolumn{1}{c}{ Namesults } \\
\hline Basin Area $(\mathrm{A})\left[\mathrm{km}^{2}\right]$ & 23.5 \\
Basin Perimeter $(\mathrm{P})[\mathrm{km}]$ & 21.6 \\
Axial Length $\left(\mathrm{A}_{1}\right)[\mathrm{km}]$ & 7.1 \\
Length of the main channel $(\mathrm{Lc})[\mathrm{km}]$ & 7.8 \\
Form Factor $(\mathrm{F})$ (Horton. 1932) & 3 \\
Compactness Factor $(\mathrm{Kc})($ Gravelius. 1914) & 1.3 \\
\hline
\end{tabular}

Drainage network parameters (Table 7): They resulted in a basin with drainage orders from 1 to 5 according to Strahler's methodology with predominantly dendritic and parallel patterns in the upper zones of the basin, which reflect different runoff regimes in the basin (Figure 6). On the other hand, according to the classification of Gil et al. [69], Senciales [70], Sala and Gay [71], and Sanchez [72] with respect to the Bifurcation Ratio (Br) and Length (Lr), this indicates that the basin would present a significant rapidity of flow waves, and also confirms that it is a rounded basin with a greater concentration of runoff along the main channel; these values usually represent the highest flow hazards due to sudden concentration of runoff.

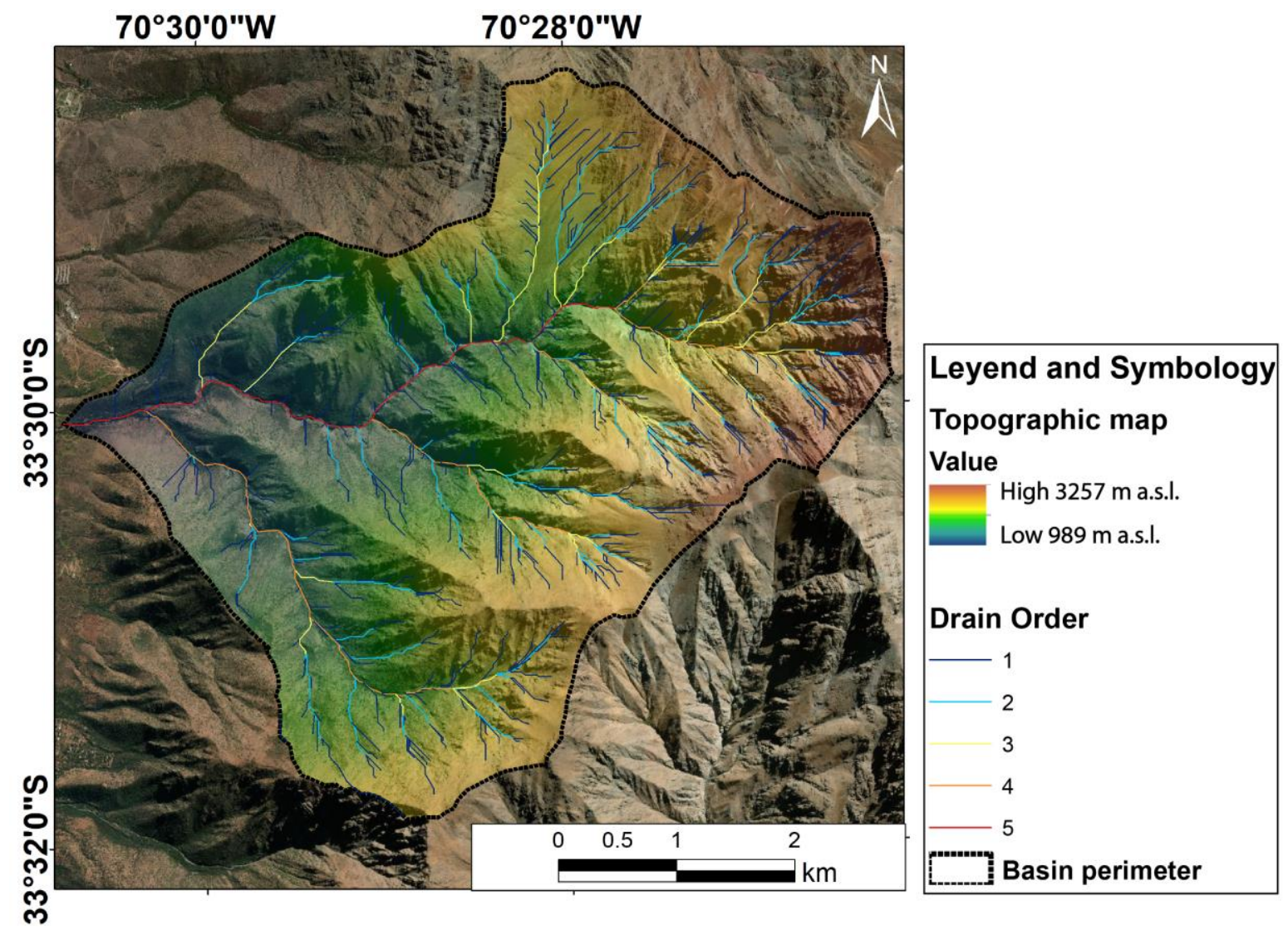

Figure 7. Macul basin, where the topographic map is shown, in addition to the result of the delimitation and obtaining of the perimeter and area of the basin and the generation of the drainage networks according to their orders based on the methodology of Strahler [68] by means of morphometric analysis. 
Table 7. Result of the morphometric analysis of drainage system parameters.

\begin{tabular}{|c|c|}
\hline \multicolumn{2}{|l|}{ Drainage System Parameters } \\
\hline Name & Results \\
\hline Drainage order (n) (Strahler, 1964) & $1,2,3,4$ and 5 \\
\hline Bifurcation ratio $\left(\mathrm{B}_{\mathrm{r}}\right)$ (Strahler, 1964) & 1.8 \\
\hline Length Ratio $\left(\mathrm{L}_{\mathrm{r}}\right)$ (Strahler, 1964) & 0.9 \\
\hline Density of the drainage network (Dd) (Horton, 1945) [1/km] & 6.1 \\
\hline $\begin{array}{l}\text { Drainage Frequency (F) (Ordoñez, } 2011 \text { in Garay \& Agüero, } \\
\text { 2018) }\left[1 / \mathrm{km}^{2}\right]\end{array}$ & 40.3 \\
\hline Drainage hierarchy $(\mathrm{J})$ & 5 \\
\hline
\end{tabular}

Relief Parameters (Table 8): They indicate that the Macul watershed has an absolute unevenness $(\mathrm{H})$ of $2066 \mathrm{~m}$ a.s.l., in addition to having an average slope $(\mathrm{Sm})$ of $62.3 \%$ $\left(31.2^{\circ}\right)$ and maximum and minimum slopes of $276.3 \%\left(71.1^{\circ}\right)$ and $0 \%$, respectively, which can have repercussions on important rainfall runoff velocities, which can drag important sedimentary material towards areas of lower slope (Figure 8). On the other hand, the Hypsometric Curve (Figure 9), according to Guerra and González [73], allows estimating the state of potential dynamic equilibrium of the basin, under the hypothesis that this function relates altitude with area, therefore it changes with time as the basin undergoes denudation; on the other hand, it can relate the differential activity between the processes of tectonic construction and degradation by erosion, activities not necessarily related to the age of the basin. The results indicate that the Macul basin $(\mathrm{QM})$ is in an intermediate phase between a mature basin and a young basin, which in turn can be related to the relationship with the tectonic uplift of the Andes Mountains representing the endogenetic processes that affect it, together with the modeling of the surface through exogenetic processes, which translates into the denudation and alluvial and fluvial environment of the basin, represented by the presence of active transport of the basin to smaller areas.

Table 8. Result of the morphometric analysis of relief parameters.

\begin{tabular}{lc}
\hline \multicolumn{1}{c}{ Relief Parameters } \\
\hline \multicolumn{1}{c}{ Name } & Results \\
\hline Absolute elevation difference (H) [m a.s.l.] & 2066 \\
Average slope of the basin (Sm) [\%] & 62.3 \\
Maximum slope of the basin (SM) [\%] & 276.3 \\
Minimum slope of the basin (Smin) [\%] & 0 \\
Hypsometric curve (Strahler, 1964) & - \\
\hline
\end{tabular}

Complementary parameters (Table 9): The results of Tc, Ie, and Sc according to the classifications of López and Romero [56] Aracena [74], and Garay and Agüero [75] indicate that the Macul basin (QM) presents torrential characteristics, in addition to presenting more favorable conditions for the triggering of debris flow or alluvium processes, presenting a high density of drainage per basin surface, allowing rapid runoff towards the main channel of the basin, decreasing the infiltration capacity of the basin. In addition, $\mathrm{Pi}$, according to Borguel's classification [76], indicates that the basin has a high capacity for sediment accumulation, and therefore a high availability of sediments, which can result in significant sediment transport to areas of lower slope in the event of a hydrometeorological event.

Finally, the geology, the Macul basin (QM) is characterized by consolidated and unconsolidated units, (Figures 10 and 11), where a result and description of each one can be found in Table 10. The large areal extension of Tia stands out, making up 79.9\% of the basin area, however, if we take into consideration the total area (basin area and mouth area), this unit represents $43 \%$ of the total area. The importance of characterizing this formation lies in the fact that part of its area represents exposed rock in the basin, equivalent to the area of direct rainfall runoff ( $53 \%$ of the formation). On the other hand, 
the rest of the area is made up of unconsolidated sedimentary units, represented by the materials found in the alluvial beds (Qa, Qai) and on the slopes of these watersheds (Qac, Qc, Qrm), being deposited on top of a consolidated rock unit (Tia). These materials are characterized by having a varied origin and above all for not being consolidated and for presenting a heterogeneity in their composition and particle size; therefore, they do not present a resistance to downslope displacement once the alluvial flow has developed and are likely to be constituent material of these flows. The predominant unit in this case is the colluvial deposits $(\mathrm{Qc})$, which represent $9 \%$ of the basin area. Now, if we consider the basin as a whole, the piedmont deposits (Qap) would be the predominant ones, represented by $43 \%$ of the total area (Figure 9) however, the delimitation of this area is approximate [9], so this percentage can vary. It is affected by faults that affect the Abanico Formation and part of the unconsolidated sedimentary deposits, highlighting the active San Ramón Fault, whose movement is reverse of west vergence with a preferential NS trace.

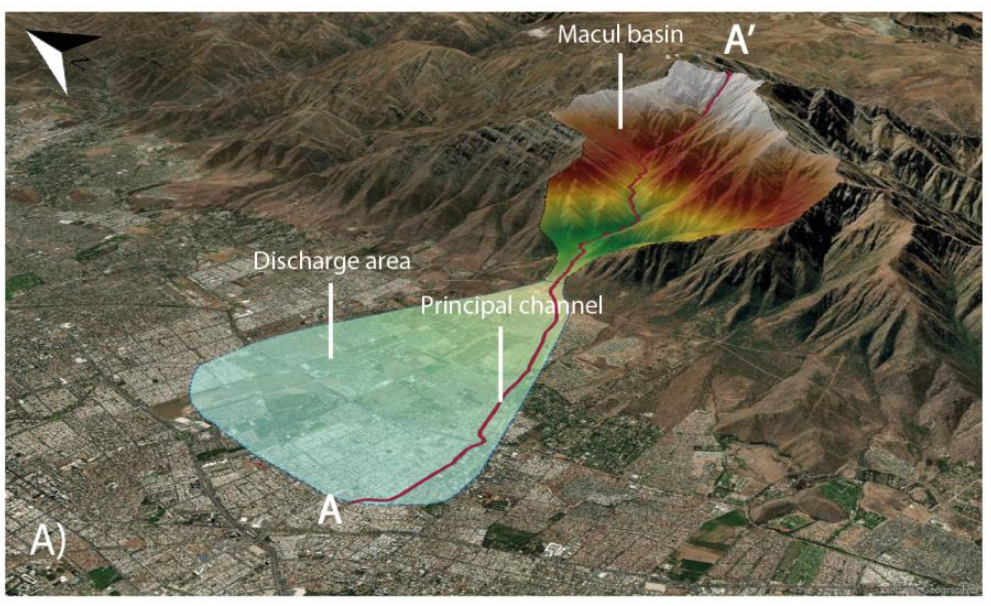

\section{Legend}

Altitude map m a.s.l.
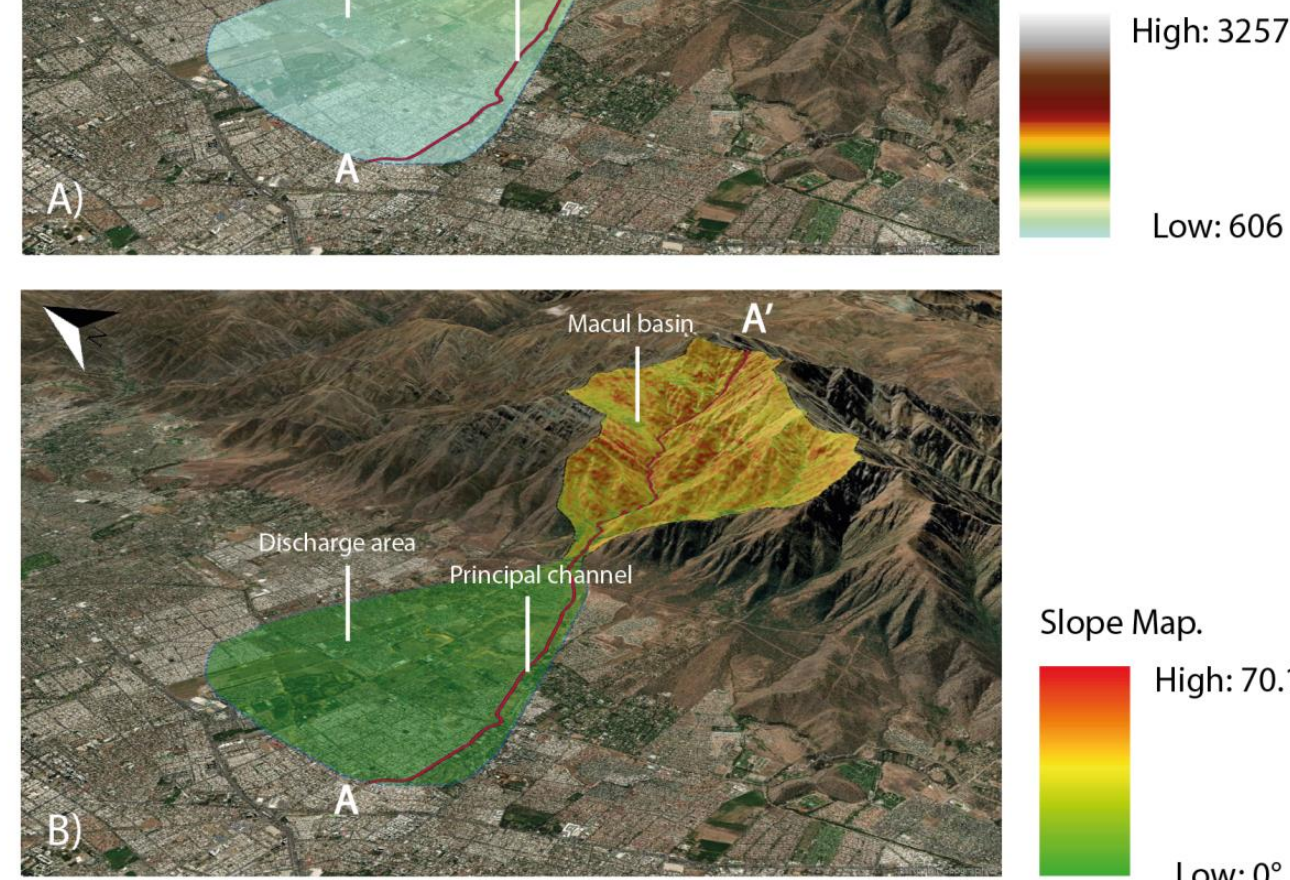

Slope Map.
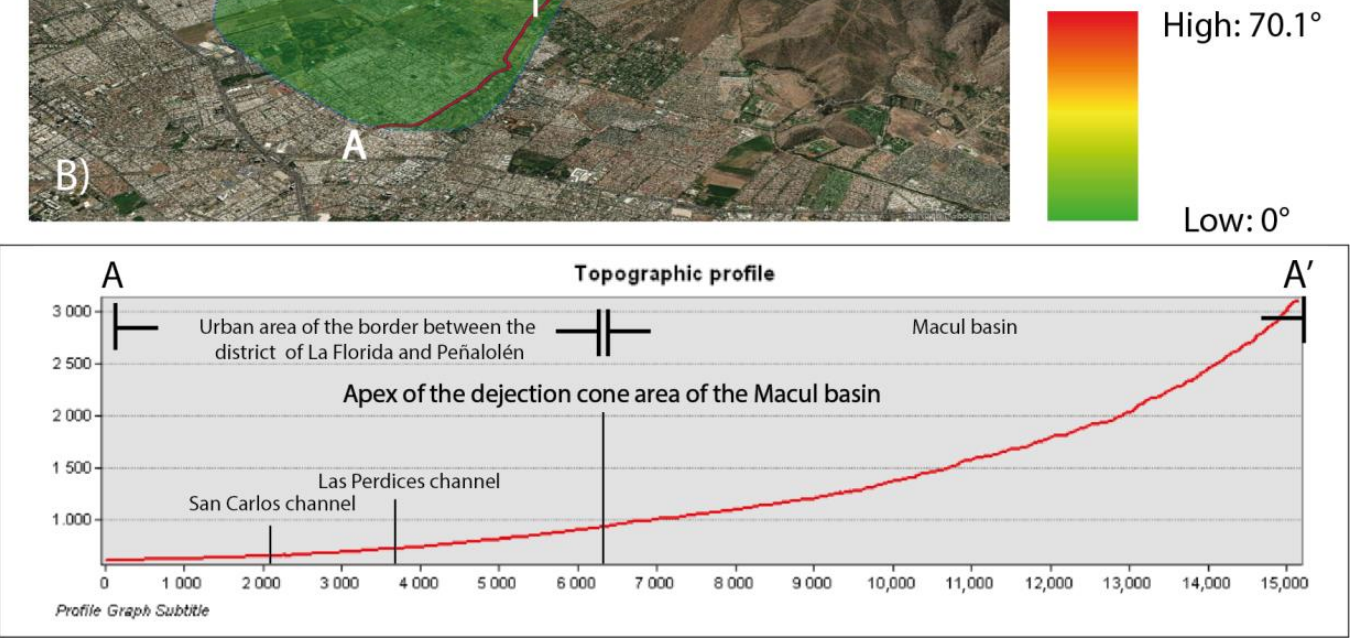

Figure 8. Morphometric maps of the Macul basin, Metropolitan Region (Chile). (A) It represents the topographic map with units $\mathrm{m}$ a.s.l. (B) Map of slopes in units of degrees. The topographic profile represents the height trends of the main channel, related in turn to the location of some urban areas. 


\begin{tabular}{|c|c|c|c|c|c|c|}
\hline $\mathbf{N}^{\circ}$ & Classes & Area ( $\mathbf{m}^{2} \mathbf{)}$ & $\begin{array}{c}\text { Accumulated } \\
\text { area }\end{array}$ & $\begin{array}{c}\text { Relative } \\
\text { area }\end{array}$ & $\begin{array}{c}\text { Average } \\
\text { elevation } \\
\text { m a.s.l. }\end{array}$ & $\begin{array}{c}\text { Relative } \\
\text { elevation }\end{array}$ \\
\hline 1 & $989-1000$ & 10,226 & 23.5 & 1.00 & 994.5 & 0.3 \\
\hline 2 & $1000-1100$ & 299,578 & 23.5 & 1.00 & 1050 & 0.3 \\
\hline 3 & $1100-1200$ & 613,445 & 23.2 & 0.99 & 1150 & 0.4 \\
\hline 4 & $1200-1300$ & 779,210 & 22.5 & 0.96 & 1250 & 0.4 \\
\hline 5 & $1300-1400$ & 996,447 & 21.8 & 0.93 & 1350 & 0.4 \\
\hline 6 & $1400-1500$ & $1,130,708$ & 20.8 & 0.89 & 1450 & 0.4 \\
\hline 7 & $1500-1600$ & $1,261,031$ & 19.6 & 0.84 & 1550 & 0.5 \\
\hline 8 & $1600-1700$ & $1,276,865$ & 18.4 & 0.78 & 1650 & 0.5 \\
\hline 9 & $1700-1800$ & $1,230,616$ & 17.1 & 0.73 & 1750 & 0.5 \\
\hline 10 & $1800-1900$ & $1,397,997$ & 15.9 & 0.68 & 1850 & 0.6 \\
\hline 11 & $1900-2000$ & $1,422,993$ & 14.5 & 0.62 & 1950 & 0.6 \\
\hline 12 & $2000-2100$ & $1,545,648$ & 13.1 & 0.56 & 2050 & 0.6 \\
\hline 13 & $2100-2200$ & $1,620,492$ & 11.5 & 0.49 & 2150 & 0.7 \\
\hline 14 & $2200-2300$ & $1,686,403$ & 9.9 & 0.42 & 2250 & 0.7 \\
\hline 15 & $2300-2400$ & $1,658,588$ & 8.2 & 0.35 & 2350 & 0.7 \\
\hline 16 & $2400-2500$ & $1,691,906$ & 6.5 & 0.28 & 2450 & 0.8 \\
\hline 17 & $2500-2600$ & $1,339,049$ & 4.8 & 0.21 & 2550 & 0.8 \\
\hline 18 & $2600-2700$ & 983,371 & 3.5 & 0.15 & 2650 & 0.8 \\
\hline 19 & $2700-2800$ & 830,030 & 2.5 & 0.11 & 2750 & 0.9 \\
\hline 20 & $2800-2900$ & 617,614 & 1.7 & 0.07 & 2850 & 0.9 \\
\hline 21 & $2900-3000$ & 516,252 & 1.1 & 0.05 & 2950 & 0.9 \\
\hline 22 & $3000-3100$ & 385,347 & 0.6 & 0.02 & 3050 & 0.9 \\
\hline 23 & $3200-3257$ & 175,829 & 0.2 & 0.01 & 3228.5 & 1.0 \\
\hline
\end{tabular}

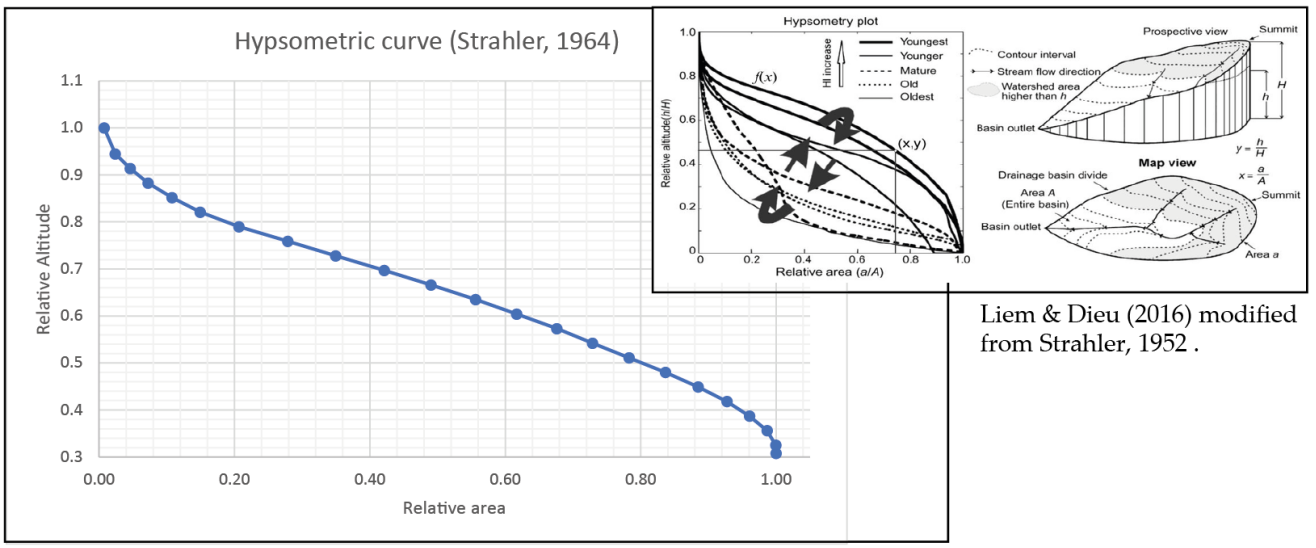

Figure 9. Values and graph of the hypsometric curve for the Macul basin.

Table 9. Result of the morphometric analysis of complementary parameters.

\begin{tabular}{lc}
\hline \multicolumn{1}{c}{ Complementary Parameters } \\
\hline \multicolumn{1}{c}{ Name } & Results \\
\hline Torrentiality coefficient $\left(\mathrm{T}_{\mathrm{c}}\right)$ (López and Romero, 1987) $\left(1 / \mathrm{km}^{2}\right)$ & 20.3 \\
Basin Efficiency Index $\left(\mathrm{I}_{\mathrm{e}}\right)($ Aracena, 1993) & 16.6 \\
Potentiality index $\left(\mathrm{P}_{\mathrm{i}}\right)($ Börgel, 1978) & 2.2 \\
Storage Coefficient $\left(\mathrm{S}_{\mathrm{c}}\right)($ Garay \& Agüero, 2018) & 0.5 \\
\hline
\end{tabular}
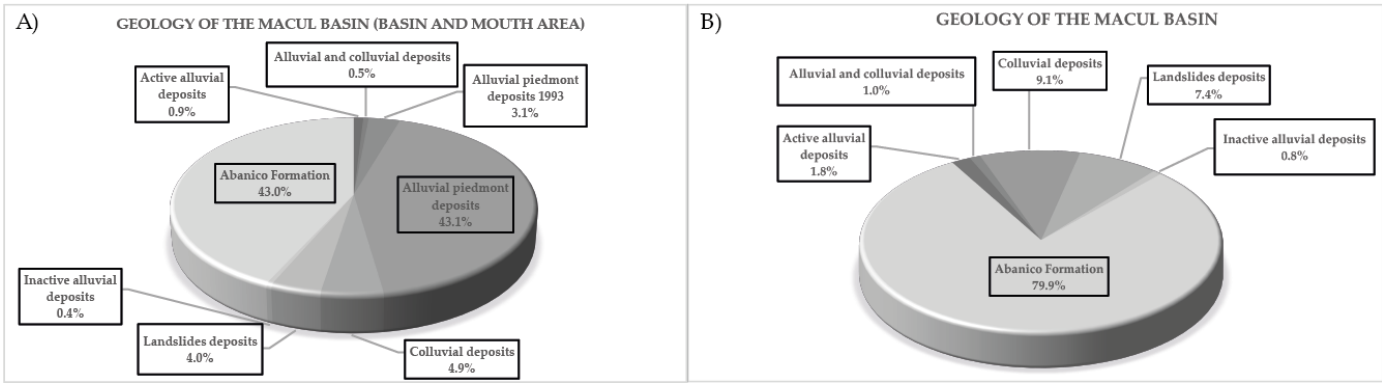

Figure 10. Areal analysis of the geological units of the Macul basin. (A) Basin and mouth area. (B) Only the Macul basin. 


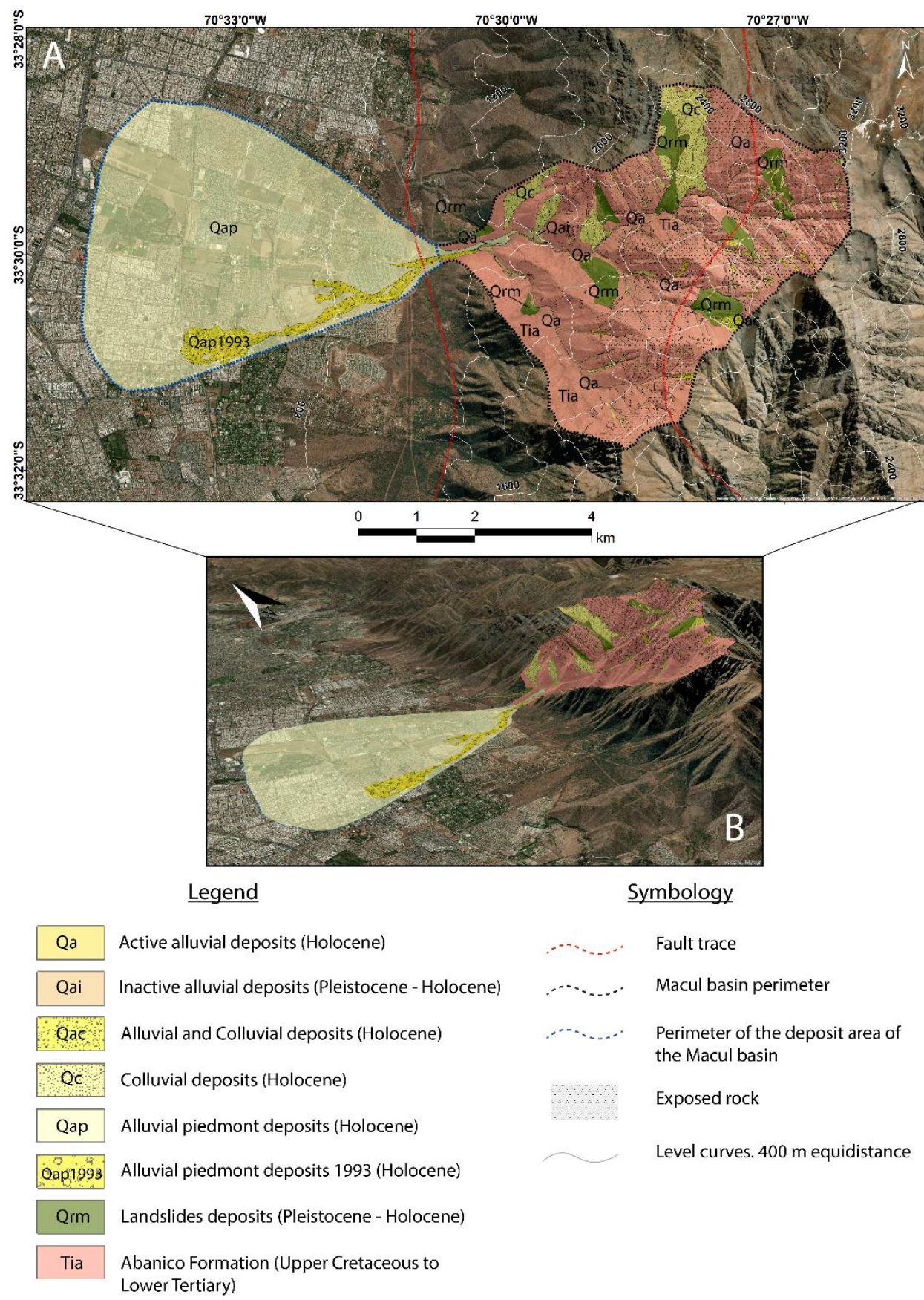

Figure 11. Geological map of the Macul basin, showing the different geological units of unconsolidated sediment and rock units that make up the basin and the mouth area. (A) Plan view of the geological map. (B) Relief view of the geological map. 
Table 10. Geological units belonging to the Macul basin.

\begin{tabular}{cl}
\hline Code & \multicolumn{1}{c}{ Description } \\
\hline & $\begin{array}{l}\text { Active alluvial deposits (Holocene): Fluvial and alluvial clastic sedimentary deposits filling active ravines and } \\
\text { gullies where some streams flow, whose deposits come out on less steep areas known as piedmont (Qap and Qap }\end{array}$ \\
Qa & $\begin{array}{l}\text { 1993). These deposits are composed of non-consolidated to slightly cemented and apparently unlayered gravel, sand, } \\
\text { clays, and silt, having variable thicknesses and showing grayish-brown colors. Gravel deposits are predominantly } \\
\text { matrix-poor, and they contain polymictic and polymodal angular and subangular clasts with moderate sphericity, } \\
\text { mainly coming from Abanico Formation (adapted from Moreno et al., 1991 and Naranjo \& Varela, 1996). }\end{array}$
\end{tabular}

Alluvial and colluvial deposits (Holocene): Active and inactive alluvial and colluvial non-consolidated clastic sedimentary deposits, which are primarily located on active ravines and at the foot of the slopes. These deposits are composed of gravel, sand, silt, and clays to a lesser extent. The gravel is polymodal, occasionally matrix-rich

Qac containing subrounded to angular clasts, furthermore its lithology is influenced by the surrounding rocks, especially by the ones from Abanico Formation. The matrix proportion is variable and composed of grains ranging from clayey silt to sand showing grayish-brown colors (adapted from Moreno et al., 1991).

Colluvial deposits (Holocene): Diamictic clastic sedimentary deposits that have a highly heterogeneous granulometry ranging from boulders to clayey-silty matrix with angular clasts, whose lithologic composition

Qc corresponds to the surrounding rocks. The amount of matrix is higher than the amount of clasts, being, therefore, matrix-rich. These laminar deposits develop steep slopes around 20 to $25^{\circ}$ at the foot of the exposed flanks setting up thick cone-shaped piles, which in some cases reach tens of meters. Created by mechanical and chemical weathering. Its age is primarily Holocene (adapted from Moreno et al., 1991).

Piedmont alluvial deposits 1993 (Holocene): Represents the technical record of the urban area affected by flows of alluvial sediments on 3 May 1993. They are represented by torrential-alluvial clastic sedimentary deposits which are fining-upward from the apex of the alluvial fan to its distal zone, due to the energy dissipation caused by the spread of the flow at a less steep slope. The deposits reach an estimated volume of $1 \times 10^{6} \mathrm{~m}^{3}$ with a volumetric concentration of $40 \%$, liquid and solid flow of $72 \mathrm{~m}^{3} / \mathrm{s}$ and $48 \mathrm{~m}^{3} / \mathrm{s}$, respectively. They are composed of mud and

Qap 1993 debris flows including clays, silt, sand, and gravel with boulders of up to $5 \mathrm{~m}$ in diameter, eucalyptus trunks, and anthropogenic material as well. Some records show the development of two main flow waves, each of them having particular features; the first flow wave was $1 \mathrm{~m}$ high $(<1.2 \mathrm{~m})$ reaching speeds close to $15 \mathrm{~km} / \mathrm{h}$ and sweeping rock boulders of up to $1 \mathrm{~m}$ in diameter, eucalyptus trunks and grayish mud along. The second wave was made up of mud and debris flow that surpassed $3 \mathrm{~m}$ in height reaching speeds up to $30 \mathrm{~km} / \mathrm{h}$, being this one the most harmful wave (Ayala \& Cabrera, 1996).

Piedmont alluvial deposits (Holocene): Torrential-alluvial clastic sedimentary deposits arranged in various alluvial fans covering from the apex of Macul basin and its ravines that cross the western part of the Andean Range and join to each other on the middle and distal part to set up an only sloping surface. The sediments are comprised of sandy gravel with some alternating sand beds that show a decrease in the coarser grains size from $1.5 \mathrm{~m}$ in diameter in the apex of the fans to $1 \mathrm{~m}$ in the middle part. The grain size keeps diminishing to the distal zone, increasing in turn, the amount of sand. Internally, they are poorly or non-layered. The origin of these deposits is given by the intermittent torrential input from high energy water streams, which interfingers with newer deposits, just like the piedmont alluvial deposit of 1993 (adapted from Moreno et al., 1991 and Naranjo \& Varela, 1996).

Inactive alluvial deposits (Pleistocene-Holocene): Alluvial and fluvial clastic sedimentary deposits, which fill ravines and gullies where some streams flow, developing low slopes and inactive alluvial fans. It is comprised of gravel, sand, silt, and clays to a lesser extent, developing stratification surfaces locally and variable thicknesses. Gravel is mainly matrix-rich, having polymodal grains from $1 \mathrm{~cm}$ to $3 \mathrm{~m}$, subrounded and polymictic, comprised predominantly of Abanico Formation clasts. The matrix is composed primarily of coarse sand to grayish-brown silt-clays. To the top, it shows the development of vegetation and a soil horizon (adapted from Moreno et al., 1991).

Landslide deposits (Pleistocene-Holocene): Clastic sedimentary deposits formed due to landslides that affected rocks, debris, or soils in moderate to steep slopes. Comprised of diamictic sediments of angular clasts, polymodal

Qrm and monomictic. The clasts are surrounded by a matrix mainly composed of a mixture of sand, silt and, clay.
The thickness varies depending on the deposit location and the deposits show brownish-yellow colors, which are a distinctive feature. The age ranges from the upper Pleistocene to the Holocene (adapted from Moreno et al., 1991 and Naranjo \& Varela, 1996).

Abanico Formation (Upper Cretaceous to Lower Tertiary): Stratigraphic sequence of sedimentary and volcanic rocks, the latter are tuff and volcanic breccias having alternating gray-brown to violet grayish-red effusive volcanic

Tia rocks, which in some close areas have an estimated thickness of $3000 \mathrm{~m}$. Particularly, in some areas there is a development of regolith that could or not have vegetation. Its Upper Cretaceous to Lower Tertiary age is given based on its stratigraphic relationships and fossil-bearing interbedded sedimentary rocks (adapted from Thiele, 1980). 


\subsection{Built Environment}

\subsubsection{Water Pipelines and Critical Hydraulic Infrastructures}

It is often argued that the Zanjón de la Aguada is born in QM and corresponds to one of the main natural channels of the Greater Santiago metropolitan area [77]. However, the history of the area suggests that this is not exactly the case, but instead the result of new water pipeline systems and hydraulic infrastructures that interacted critically with the geological environment of the basin already described.

Historical sources refer to the connection of QM with the Zanjón and also the construction of a channel to connect the Maipo River with the Mapocho to avoid agricultural droughts [78] (p. 91). In 1742, it was already indicated that there was a need to open up a ditch in the foothills of Macul to this end (Figure 12). In 1772, it was pointed out that there was "a ravine over which it was necessary to build an aqueduct that was to join the southern and northern rivers [...] which was also open, over an extension of several blocks, with very little time left to reach the Zanjón" (Emphasis added) [78] (p. 46). Around 1820, it was insisted that "six drains be opened from the Ugareta gully to the Mapocho, in the watering hole [...] in the Macul estuary [...] and at other points as necessary to prevent the flows" (Emphasis added) [78] (p. 84). Furthermore, in 1861, the indication of a "channel to be opened to the waters of the stream" was reiterated (Emphasis added) (Figure 13).

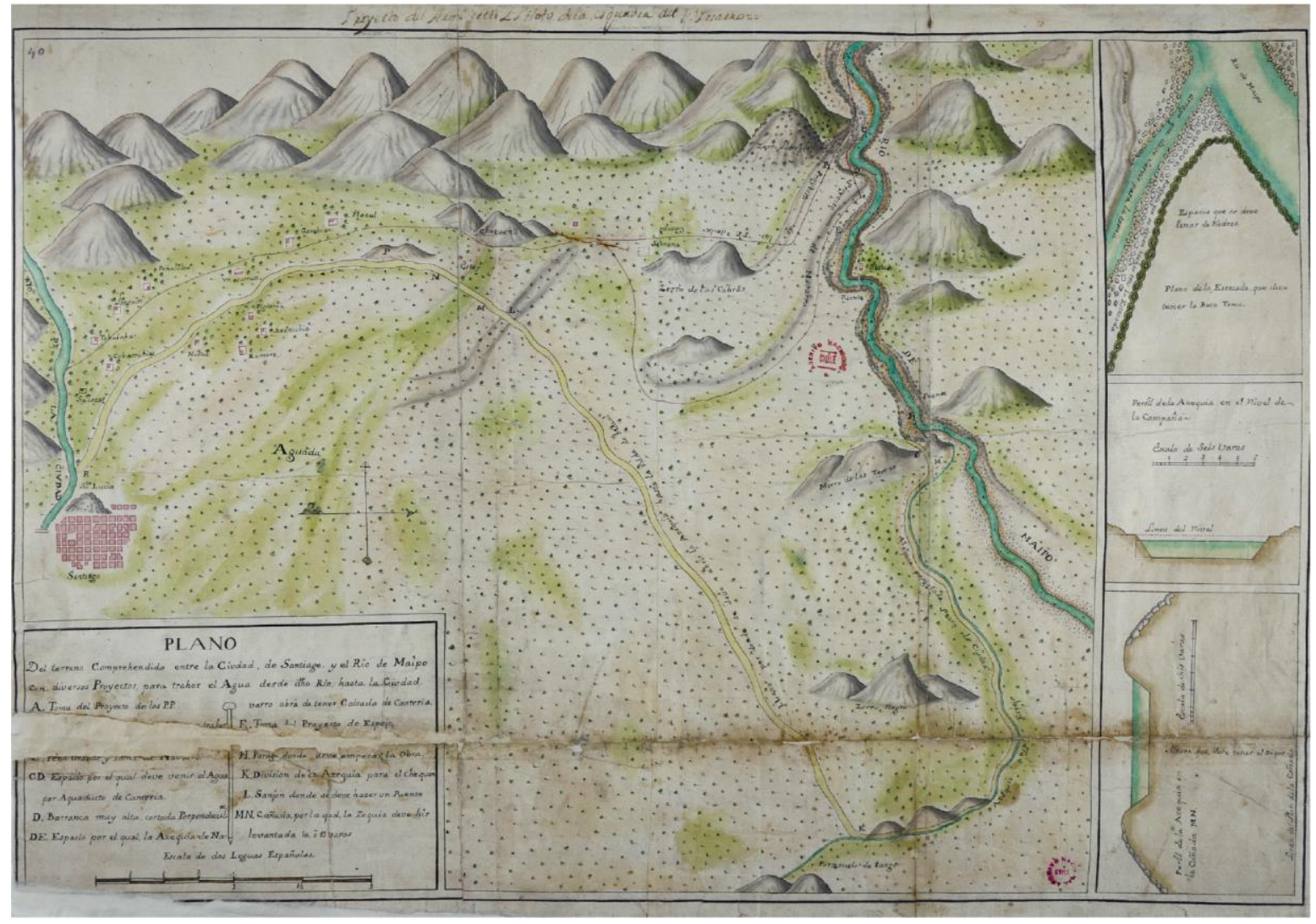

Figure 12. 1742 Plan of the land between the city of Santiago and the Maipo River with various projects to bring water from the high river to the city. At the center of the image there is an estuary represented in yellow that says "Plain where the ditch must be opened up to the skirt of Macul" [79].

Although the exact date when Zanjon joined the QM estuary is unknown, by the end of the 19th century its connection was established resulting in an inundation of problems. In 1899, "Neighbors of San Miguel detected that the cause of that [flows] was the conversion of the trench, at the level of the chacarilla of Macul, into a channel for irrigation... reason why it had stopped being a natural drainage" [81] (Emphasis added) (p. 2). Inundations 
left dozens of victims and fatalities [82] and continued to be a hazard in the 20th century. In 1982, a flow collapsed the Las Perdices bridge (Interview J.A., July, 2019) and in 1984, the irrigation channel burst [83]. The disaster of 1933 ended up causing the overflowing of the three main channels.

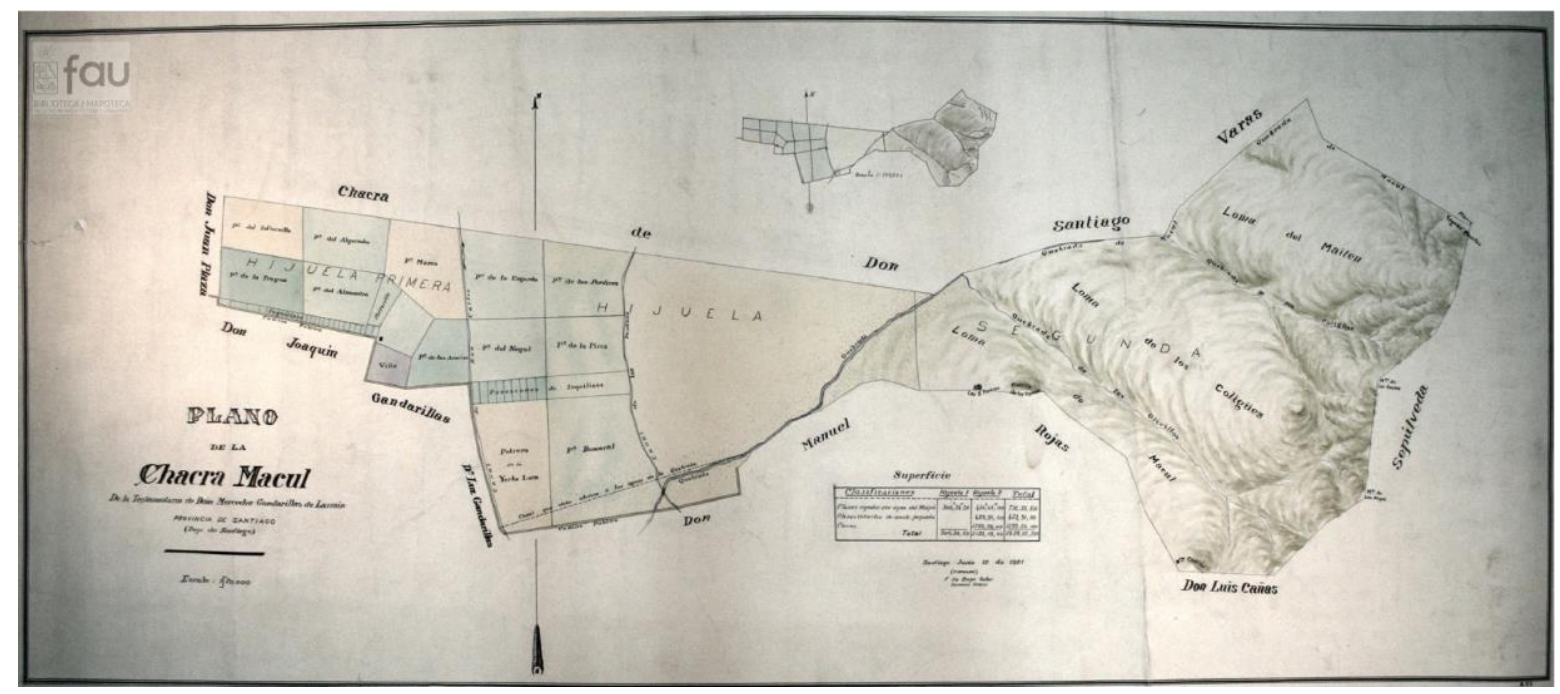

Figure 13. 1861 Drawing of the Macul farm of the testamentary Mrs. Mercedes Gandarillas de Larraín. It can be seen the basin, QM and the "channel to be opened to the waters of the stream" downstairs [80].

In addition to the construction of bridges and canals in the mouth area, local histories and accounts indicate that during the 20th century, the owner of Fundo [estate] Las Pircas built a dam in the ravine for fish farming and the operation of the "Quebrada de Macul Drinking Water Plant" [84] (This water plant was destroyed by the 1993 event, and replaced by one built a few meters below the vestiges of the original. According to Aguas Andinas [water utilities operator] it was built to supply drinking water to the residential sector of Las Pircas (Observation Notes, August, 2020).

In summary, Zanjón de la Aguada was originally a natural stream of drinking water for Santiago that began to be intervened for agricultural purposes around the 19th century. This anthropic intervention resulted in early inundations in the eastern and western areas of Santiago. These interventions were part of a larger network of canalizations and hydraulic infrastructures that were built in the 19th and 20th centuries in Santiago's piedmont. The plans carried out to connect the Maipo and the Mapocho rivers-which included management protocols, hydraulic works, and water catchments-interfered critically with the geological environment through the modification of alluvial deposits, natural riverbeds, and the hydrological regime of rivers. These interruptions were critical elements influencing the characteristics, intensity, destructive power of the flow, and scale of future alluvial events.

\subsubsection{Piedmont Urbanization}

The urban expansion in the piedmont sharpened the effect of the previously mentioned hydraulic interventions. Urbanization began in 1952, initially unfolding in the northwestern limit of the basin. In the 1960-1982 period, the rate of urban development increased significantly [23]. This forced, in 1984, the expansion of the municipality's urban limit [10], an expansion that did not account for the hydro-geological particularities of the territory [85]. Thus, by 1993, the study area was not only occupied by large hydraulic infrastructures, but also by an expanding urban population [10] that shared the territory with remaining informal settlements that located near the riverbed as a result of a general pattern of illegal land occupation that began in the 1960s [86]. 
It is important to highlight that even after the 1993 event, urban expansion has continued, and even intensified. After the disaster, informal settlements were relocated [10] and exclusion zones were enforced [23] following new land use codes that demanded mitigation measures for any new construction near the watercourse [87]. The result, rather than moderating the area's urbanization, was a sharp increase in residential developments in the QM zone, particularly in the 1992-2012 period [87]. In 1998, the "Santa Sofía de Macul" real estate project was approved, "marking the beginning of large-scale urbanization of the Florida foothills, replacing nearly 250 hectares of native vegetation with housing" [88] (p. s/n). At the same time, the construction of "Las Pircas" project began on the north bank [89] of the QM basin, and in 2004 the "Lomas de Lo Cañas" project, located by the Santa Sofia Creek's excretion cone south of QM [88] also began its construction.

As a result, by 2005, the Macul-San Ramón basin had the highest levels of urban occupation in eastern Santiago [12]. By 2018, it was estimated that residential land use of the area was 1591.9 hectares [87]. Rural roads continued to be paved to ensure "the normal runoff of water and the protection of the edges and slopes" [90] (p. 111). Today, according to modifications intended to be made to the District Regulatory Plan, the urbanization of foothills could continue [91].

In short, the accelerated process of urbanization of the piedmont interacts problematically with the hydro-geological conditions of the area. Urbanization implies the deforestation of the vegetal cover and waterproofing of the soil cover that directly affect the infiltration time, amount of direct stormwater runoff, and sediment quality that can be displaced from the mountains [12]. Although urbanization ideally requires reforestation and permanent protection of riverbanks, the decisions related to urban planning show that its risks have been made invisible through the prioritization of real estate projects becoming an important source of risks for the inhabitants.

\subsubsection{Mitigation Works}

As a result of the 1993 disaster, the Directorate of Hydraulic Works (DOH) conducted a study for the construction of protection infrastructures for urban areas surrounding the alluvial channel of the river mouth. This consisted of seven alluvial control structures located exactly in the limit between Peñalolén and La Florida districts. The latter involved the modification of the riverbed trajectory and the construction of decanting infiltration pools placed along $1590 \mathrm{~m}$, with an estimated storage capacity of sediments and clasts of $70,000 \mathrm{~m}^{3}$ [87].

The construction of mitigation works considered historic parameters, taking into account a volumetric concentration around a $38 \%$ and a detritic flow of $75 \mathrm{~m}^{3} / \mathrm{s}$. However, research $[9,17]$ has estimated that the volume of deposits registered in the 1993 alluvium was $840,000 \mathrm{~m}^{3}$, that is to say, significantly superior to the actual retention capacity. For this reason, in 2018, DOH began a process of excavating a larger decanter on the south side of the main channel of the stream [92] (The works considered (a) Slope retaining walls, (b) System of torrent correction dikes, (c) Retention system in hollow, (d) Improvement of decanting pools, (e) Canalization with stone masonry and (f) Construction of Las Perdices Avenue Bridge [93].

\subsection{Socio-Cultural Environment}

\subsubsection{Geographic Memory of QM and First Settlements}

The geographic memory of QM and the first settlement locations show a complex socio-cultural environment that is in many ways at odds with the geological features of the area and its associated risks. According to local accounts, the alluvial channel emerges dynamic in form, time, and space. As the oldest neighbor said, "By the year 1938, 1940, the creek was not large, because all the small alluviums, which have always occurred, had scattered [the creek] along the pastures" (Interview O.Z., July, 2019). Confirming this dynamism, another informant pointed out that the creek was different in its spatial characteristics, changing locations over time: "When I arrived to this sector, I had contacts 
with the ancient people, they say that the Macul ravine had run from Quilin to where it is now" (Interview J.A., March, 2020). Other accounts evoked a ravine located on Los Presidentes street (Observation Notes., September, 2020), and the toponymy of QM street also indicates a northern location.

Other evidence of a dynamic channel is found in the field tests carried out in the sector at the end of the 1980s. Before building a complex on Quilín Street—north of QM-one informant told us that in soil tests "a lot of different material came out, including sand, pebbles, like the same [type of soil] when a river passes" (Interview J.A., March, 2020). He added that when the urbanization of QM Street began, "they couldn't lay pipes because they found a sand bank" (Ídem). Another informant said that QM morphology was not the same: "It was more here [ . . . ] It was not right as it is now" (Interview A. C., July, 2019). When we asked if the flow itself had caused the transformation, he replied "No, the canalists who made the detour changed it [...] just as they made bridges, they made everything new" (Ídem). He was referring to the mitigation works carried out after the disaster.

This report is consistent with the first settlement location according to ethnohistorical records. When the Spanish colonizers arrived, Macul alluded to an indigenous village located in the space they called "comarca" of Nuñohue. These towns, also called "pueblos de indios" [Indian towns], were sectors located in "parts of valleys or ravines, near rivers or water holes" [94] (p. 30). In fact, the settlement was located north of the current alluvial channel in the coordinates $33^{\circ} 30^{\prime}-70^{\circ} 34^{\prime}$ [95] where two spring waters came from a slope of the mountain range [96] (p. 121). As indicated in the plan from 1614 (Figure 14) there was a "ditch that comes from Macul" that "[...] goes up to the skirt of the mountain range that could be wide beynte [twenty] quadras and long" [96] (p. 121). Although it has been suggested that these waters came from the San Ramón ravine [96], the georeferencing and historical maps of the town of Macul suggest that the ravine could be part of QM old natural channel.

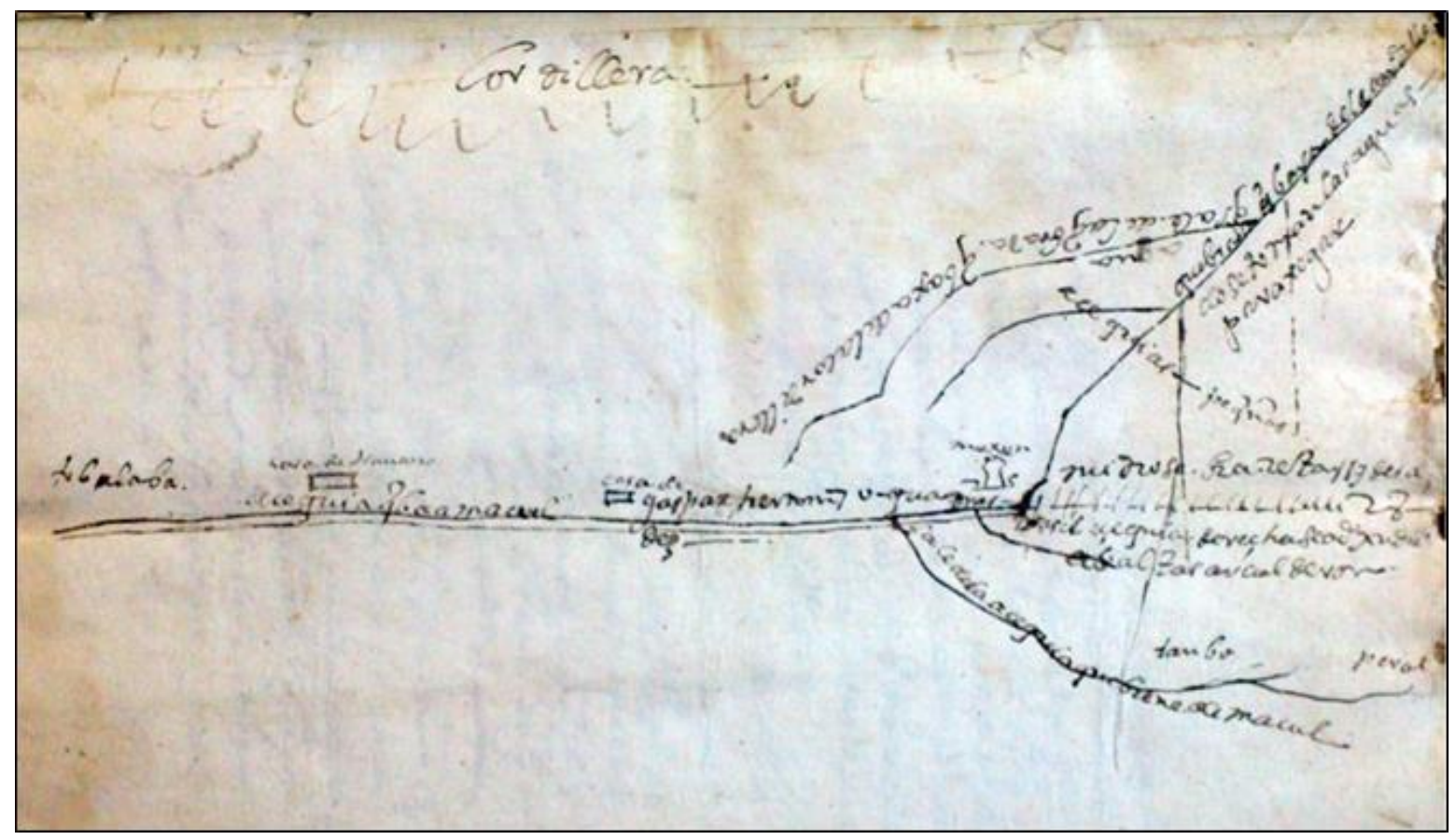

Figure 14. 1614 Plan with the location of the ditches that watered the lands of the cacique Martín de Macul [96] (p. 120).

The 16th century was a time of upheaval for indigenous peoples due to the establishment of the encomienda system and land grants, which enslaved the indigenous population and gave ownership of lands and waters to the Spanish colonizers. The indigenous town of Macul survived as an Indigenous settlement until the 18th century, a period in which, however, it was common to see old roads intervened, new bridges built for the passage 
of wagons, old irrigation ditches widened, and water courses changed for irrigation [95]. This meant a subdivision of land and intensification of agricultural productivity, giving way to a built environment that radically modified the old indigenous hydraulic structures, socio-territorial organizations, and ecological relationships.

In other words, the geographic memory of QM indicates that its natural channel would have been located in a different place from the current one due to early anthropic modifications. This makes sense with the triangulation that can be made between the ethnohistorical information of the first indigenous settlements, local memory, satellite images of the alluvial fan, and the areas of restriction indicated by the Communal Regulatory Plan (For more details see Santiago Metropolitan Ordinance Plan: https: / / ciperchile.cl/pdfs/2015/03/mineria-maipu/PRMS.pdf (accessed on 10 October 2020). or PLADECO Peñalolén 2013-2016: https:/ /www.penalolen.cl/wp-content/uploads/ 2016/10/DIAGNOSTICO-COMUNAL.pdf (accessed on 10 October 2020). And/or "Informe Consolidado de la Evaluación de Impacto Ambiental de la Declaración de Impacto Ambiental del Proyecto Modificación PRC Peñalolén": https:/ /infofirma.sea.gob.cl/ DocumentosSEA/MostrarDocumento?docId=3b /b9/f056be499fc09a8f5f8f0ddc907f13fa0a1 $\mathrm{f}$ (accessed on 10 October 2020)) that show a secondary branch of the ravine in a northern direction. Likewise, after the alluvium, the riverbed was artificially modified, changing again the natural channel direction.

\subsubsection{Memory of 1993 Alluvium and Perceptions of Risk}

Memory and risk perceptions illuminate the tensions between the geological, built, and socio-cultural environments described above, and the way local organizations make sense of them. When 1993 survivors remember the disaster, they explain it as a shared responsibility: Nature and human.

Neighbors are well aware of the anthropogenic root-causes of the disaster. As one of them said: "it has never been made explicit that man (sic) is also to blame, so don't come and say 'nature, nature, nature'" (Interview J.A., July, 2019). In fact, doing field visits with them (Figure 15) they indicated how the territory has changed over time: "Before there were farms...And up on the place where they take out gravel now, there were pastures" (Interview N.A., July, 2019). He continued: "That's the Las Perdices bridge... A tiny bridge that lasted ten minutes before being taken away [by the 1993 landslide]... If those bridges had been expedited, and if it had been cleaned up there, this [destruction] would have been much less" (Interview J.A., July, 2019).

People also remember the calicheras, or sand pits above canal Las Perdices that were exploited by local families and part of the precarious local economy. These calicheras played a critical buffering role: "when it rained the water did not run straight down the stream, but filled the calicheras with material" that would otherwise be dragged down by the flow (Interview J.A., July, 2019). However, these calicheras were banned in 1973. In lieu, in 1981, a larger sand extraction plant was built, increasing the exploitation surface area and the volume of extraction consecutively [88]. This operation altered the riverbed, exposing the accumulated material to runoff events. Another neighbor, reflecting on the rocks from the pavement of old riverbeds that the landslide dragged down the streets, asserted vividly: "the stream always asks for what was hers" (Interview A.C., June, 2019).

In sum, survivors suggest that when the geological environment interacted with an ill-planned built environment, the alluvium became a disaster. In spite of this, the exclusion zones defined after the flows impacted were arbitrarily made, and the urbanization of the piedmont contradictorily increased. Neighbors indicate that after the flow, the exclusion zone of La Higuera-one of the most affected sectors-was defined "to the taste of the consumer" (Interview S. P., June, 2020), that is prioritizing real estate considerations instead of community safety. Actually, they remember that one time the mayor of La Florida, reacting to the community's call for a better post-disaster planning, said defiantly about the definition of the exclusion zone: "If I get angry, I will draw a line like this, like this,' in a zigzag, and he scratched like this, and that's how it was" (Interview S. P., June, 2020). 


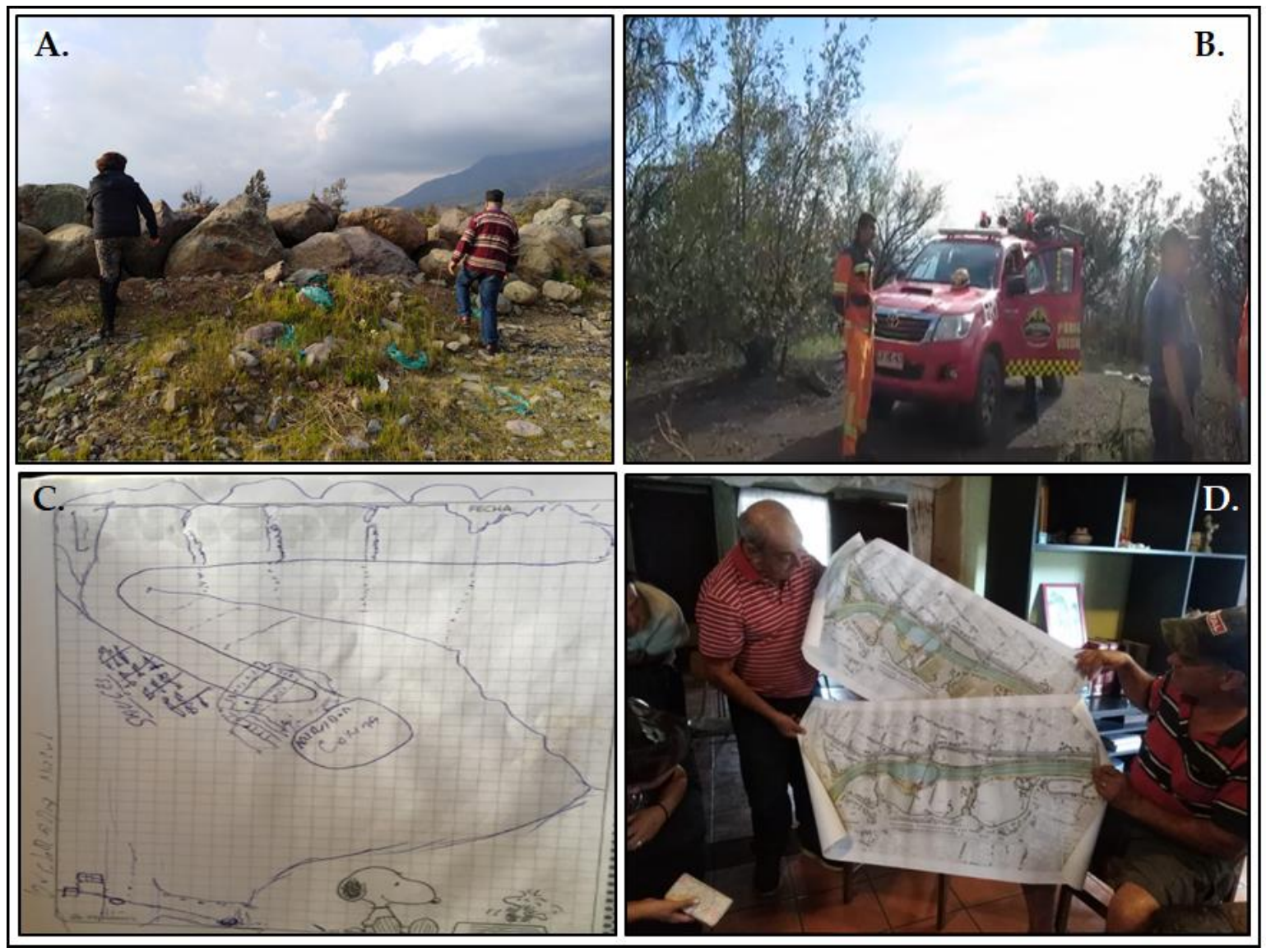

Figure 15. Activities done in the research site with neighbors and civil organizations. (A) Tour guided by old inhabitants. (B) Excursion with BEAF-Florida High Forest Brigade. (C) Neighbor drawing of the basin, vegetation, and critical infrastructures. (D) Neighbors sharing maps of floodable park project in a communal activity.

In this regard, local organizations claim that urban planning has made risks invisible as a result of real estate pressure. "how do they authorize all that," they ask, "how do they authorize the construction of houses a meter and a half away from a ravine?... they have no idea of the consequences, there are schools and infant schools half a block from the stream ... the drains are just not enough" (Interview N.A. \& J.A., July, 2019). New residential projects, moreover, have not replaced the original vegetation cover with a proper reforestation process (Figure 16).

As a response to these conflicts and gaps, community organizations have implemented different risk reduction strategies, establishing multi-sectoral collaborations. In fact, they invited us to participate in the communal emergency plan whose main objective is to elaborate a "Protocol for Emergencies and Disasters limited to the territory, updated and specific to the local reality, which will define the organization and responsibility to act in situations of Emergencies and Disasters" [97] (p. 4).

In sum, our results suggest that the disaster of QM cannot be understood from the geological environment alone. The socio-cultural environment, composed of memories and social perceptions of risk, shows how the geological and built environment interact, within the specificities of local occupational patterns, in the compounding of the disaster. 


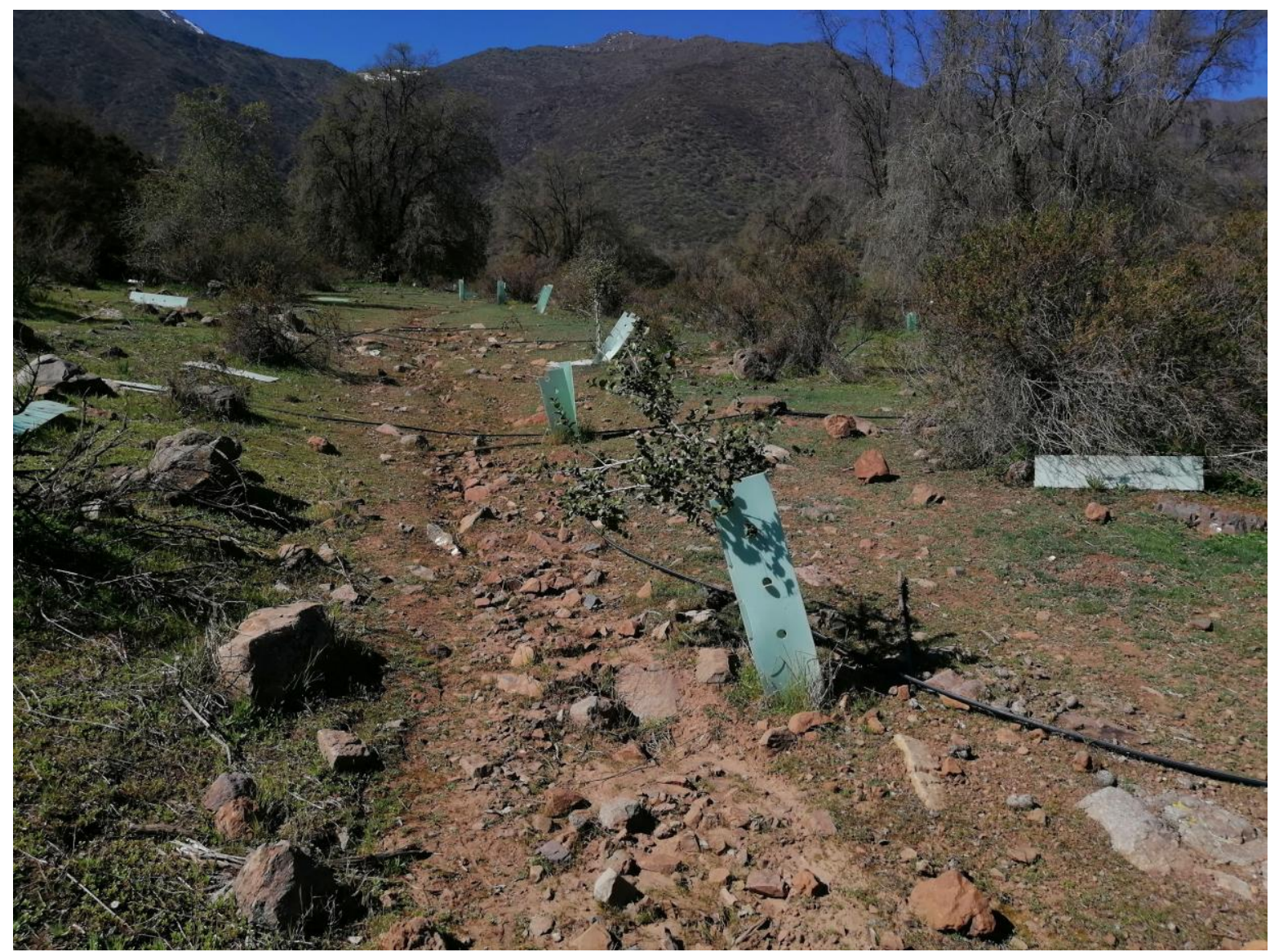

Figure 16. State of reforestations in the south west of Alto Macul real estate project. Source: Authors' photographic archive.

\section{Geo-Social Model: Mapping Environmental Interactions in the Macul Basin}

As an exploratory methodology that seeks to render visible, through transdisciplinary processes, the interactions between the geological, built, and socio-cultural environments, the Geo-Social Model can be translated into a geo-social map of the Macul Basin (Figure 17). This map, as an exercise in making the complexities of the territory public, contributes to a better understanding of the alluvial phenomenon, and hence emerges as a relevant conceptual and methodological tool for landslide risk reduction and prevention in the future.

The geo-social map (Figure 17) shows and synthesizes an evident intersection between the three environments. The estimated perimeter of the mouth of the alluvium-that is part of the geological environment-overlaps with the built environment because it is mostly urbanized (PUA and AU) except for the few agricultural and grading areas that remain in the area (AATG). In addition, as we already showed, the artificial channel Zanjón de la Aguada (ZDAC) intercepts perpendicularly with the two main water channels of the study area-Canal Las Perdices (LPC) and San Carlos (SCC) — forming the critical area of the disaster where, in effect, is the alluvial fan of the 1993 event (FAF 1993). In this area, hydraulic infrastructures identified (MAB and MIB) are critical due to the earlier connection established between the QM and the Zanjón de la Aguada, which is estimated according to historical records in the 19th century. It is also visualized that the zones of restriction or exclusion of construction (EEEZ and LHEZ) are inhabited by old houses and a recent informal settlement (TD) as evidenced by the socio-cultural environment. The zone of mining extraction (AMEAS and ASMEZ), which is part of the built environment, currently covers an area of $365,886 \mathrm{~m}^{2}$ of the alluvial fan and can increase the detritic material of the alluvial flow and therefore its destructive power because of the unconsolidated material and its location close to the main channel. Upstream, at the apex of the river mouth, is the drinking water plant (PWP), considered as a critical infrastructure that can provide solid 
and liquid material, as it is exposed to the trajectory of a possible alluvial flow, due to its location and for not containing protection works.

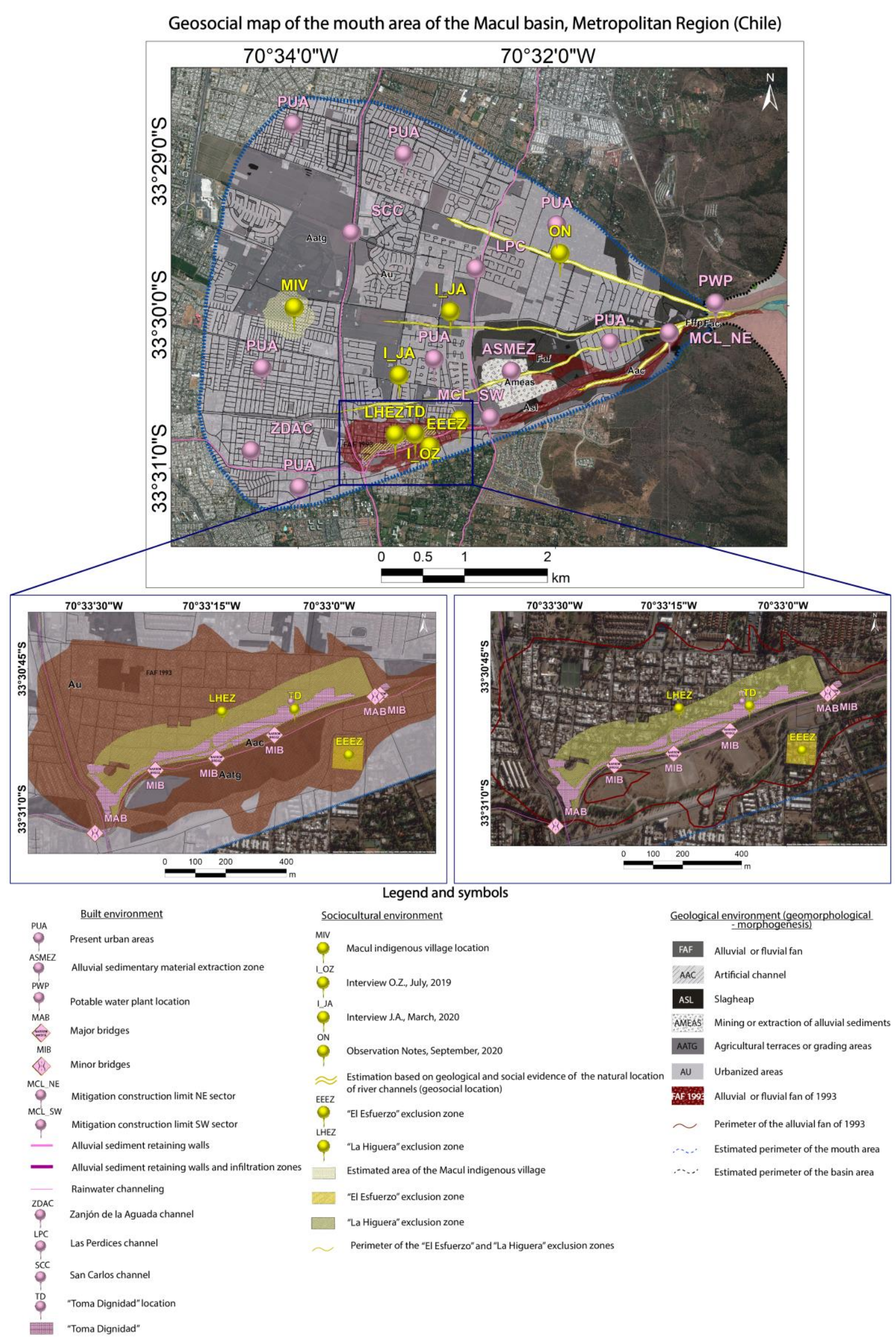

Figure 17. Geo-social map of the discharge (or mouth) area of the Macul basin, Metropolitan Region (Chile). 
Mitigation works (MCL_NE, MCL_SW) located in the southern zone of the mouth area, have a preferably southwestern trajectory, and form the so-called artificial channels (AAC). This particular trajectory represents a problem in terms of the lack of protection of the northern area of the alluvial fan (FAF), which in turn is made up of agricultural areas and mainly urbanized areas (AU) whose construction is relatively recent. This is because according to estimates based on geological evidence (Deposits of piedmont and alluvial fan, FAF 1993) and social evidence (Testimonies I_JA, I_OZ,ON and MIV ethnohistorical sources), the natural trajectory of the channels is possibly in a west and northwest direction, specifically along Quilin Norte street, and areas near Los Presidentes Avenue mainly coinciding with the Las Pircas neighborhood (channel geo-social location). More proof of this is the ethno-historical evidence reported by the socio-cultural environment, which indicate, based on geographical coordinates of the historical record, that the indigenous settlement of Macul (MIV) was located in the western area of the mouth of the river, coinciding with Quilin Norte street (I_JA). To this is added that the indigenous peoples used to be located in sectors bordering the natural trajectories of water, which allows us to conclude that the natural course of QM is coincident with the area mentioned above (I_JA). In other words, both the current riverbed and the mitigation works are part of a built environment that comes into conflict with the geological and socio-cultural environment of the area of study, this could lead to socio-natural disasters if are not considered in the future urban planning.

\section{Discussion}

Although several research studies have been developed around landslides [52-54,98-101], there is still a need to deepen the understanding and characterization of their main conditioning and triggering factors and their in a context of anthropogenic intervention.

Based on this, from the geological discipline, several investigations have been carried out in the Macul basin, inspired mainly by the great impact on urban areas of the alluvial event of 1993 and the subsequent minor alluvial activations in the basin. For instance, Naranjo and Varela [17] conducted a geological analysis of the causes, mechanisms, and effects of the 1993 event, inferring that the main conditioning factor was the large accumulation of unconsolidated sediments in the basin, which came from previous events deposited mainly in the alluvial channels, and inferring that the intense rainfall was the main triggering factor. However, like this research, Ayala and Cabrera [9] indicate that the development of landslides is not only influenced by unconsolidated sediments, but also by the characteristics of other triggering factors.

The latter was the first research studying the vulnerability of certain urban areas in relation to areas possibly impacted by flow-type landslides. In this regard, Naranjo and Varela [17] made a zoning of the 1993 impact area in Macul with field data and Garrido [102] zoned areas for possible impacts using LAHARZ and MSF (Modified Single Direction Flow Model) algorithms, giving results relatively close to the zoning provided by Naranjo and Varela [17]. The MSF model shows the three most probable directions for impact by flowtype landslides, which are quite close to the actualized results provided by the geo-social map. On the other hand, Martínez [21], uses the Weighted Map Overlay methodology with the IS Susceptibility Index by applying a methodology of Lara [58], making an advance in the application of conditioning factors, but disregarding within these the anthropogenic influence on its development.

As can be seen, although these investigations represent an important advance in the knowledge of these factors, there is still a lack of consensus in the determination of the main determinants of river landslides. However, the morphometric analysis is in a certain way complementary since it gives good results in terms of determining the response of the basin in a quantitative way, which confirms what was delivered in the geological analyses and by landform regarding the fact that the Macul basin (QM) has optimal characteristics for the development of debris flows $[56,69,71,77]$. In addition, its results can be used as a complementary analysis or as a qualitative method validation methodology, taking 
into account that the greatest weakness of this analysis is its absolute dependence on the quality of the digital elevation model, in addition to the inaccuracy of ranges inherent to any analysis.

Additionally, they tend to underestimate the anthropogenic influence in the development and magnitude of the impact of threats due to the difficulty that this entails. In this scenario, the problematization of flow-type landslides through the Geo-Social Model and a transdisciplinary approach can help to clarify this conundrum, providing advances in the way landslides are understood and assessed.

In general, even though many studies recognized the role of humans in landslide processes, there are few reviews about this topic; and conceptual and methodological problematizations $[103,104]$. Indeed, landslides are more commonly attributed to have been caused by heavy rainfall [4], but as the results of the Geo-Social Model show, landslidesparticularly in urban contexts-are often the result of anthropogenic disruptions of natural balances and systems. This is coherent with other studies carried out recently worldwide that started to conceptualize landslides as Human-Induced Landslides (IHL) that is to say, events that are "triggered or partially aggravated by anthropic activities" [104] (p. 217).

More specifically, the results of the built and socio-cultural environment are oriented in this direction showing that anthropic activities are the result of interventions that are the effect of long histories of infrastructuring, urbanization, and occupation of the geological environment that while exceed the memory of current inhabitants, are passed intergenerationally, and registered in the material and cultural trajectories of the community and its perceptions of risk.

In first place, infrastructuring took form in QM via water canalizations that changed the natural channel for agricultural purposes in a long-term duration perspective and also through the construction of critical hydraulic infrastructures. In this regard, QM research does not point out histories of infrastructuring and its influence in landslides; from a worldwide perspective, there are few examples that account for these important triggering factors but they are coherent with the Geo-Social Model results. For example, in Belgium, Preuth et al. [105] has shown that water pipes crossing active landslides caused deformations increasing the negative effect of water. In addition, Jaboyedoff et al. [104] confirm that small modifications of slope topography or diversion of a surface water collector may induce landslides in many cases. Additionally, river erosion caused by modification of the course can produce landslides because it can change the course or the debris flow initiating new erosion banks which can promote landslides [106,107]. As Sepúlveda and Petley [108] have argued, this lack of evidence may be explained due to a research deficit in Latin America and the Caribbean, where the mechanisms are not yet well understood, distribution causes and triggers of landslides.

Secondly, the rapid urbanization process experienced in QM evidenced occupation of hazard prone areas and pavimentation of original rural roads extending as a main regional problem has already been pointed out by national research and local organizations. The latter can be understood in low- and middle-income countries as a consequence of a badly planned and poorly managed urban expansion [109]. In effect, it is well known that landslide vulnerability in mountain environments is increased in dense urbanization areas and/or where precarious squatter settlements have developed at the foot of slopes [3,4,26,108,110,111].

Thirdly, the geographic memory of QM indicates-for the first time-that its natural channel would have been located in a different place from the current one due to early anthropic modifications. Furthermore, the local memory of the event indicates the anthropogenic root-causes of the disaster, and social perceptions of risk show both the deficiencies of urban planning but also prevention strategies implemented locally as some scholars had already shown in QM in the past. This is coherent with Ullberg's concept of 'memory scape' [112-114]. In the field of social sciences, this refers to the dynamic configuration of memory in disasters, constituted by memories, forgetfulness, and reminiscences that are expressed through multiple ways, ranging from everyday practices, 
public documents, rituals, monuments, signs, and all kinds of physical signs that became part of disaster landscapes. As is argued by Masi [115], this concept is a valuable input for recognition and understanding of social behaviors, which are not only gravitating as demands of explicit statements of public interventions, but essential when formulating public policies on risk management and disaster mitigation.

The geo-social map, as an experimental and exploratory tool for mapping the environmental interactions in the Macul basin (QM), is an exercise of making the aforementioned territory complexities visible and useful for the community. Even the appropriate consideration of different risk perceptions, social, political, and institutional aspects are essential for successful risk management [116]. There is still limited experience on how technical risk analysis can be applied in areas with scarce or absent data as it happens in developing countries of Latin America, and also how it can be effectively combined with communitybased risk management approaches [117]. As a result of a transdisciplinary approach for landslides analysis and prevention, the geo-social map through a TDA approach functions as a primary tool to understand the complex geo-social characteristics of flow-type landslides and to inspire new modes of making hazard assessments in the future hand in hand with communities affected by landslides.

As Takeuchi et al. [118] and other scholars have shown, TDA practices have not been widely exercised both in discipline and in actions. Even there are few examples worldwide that apply this approach, one of the main differences between this research and others carried out is the attempt of co-production of knowledge connecting epistemologically different disciplines and actors to create holistic approaches using concepts and methods originally created in other disciplines, to relate, integrate, bring together, synthetize, and merge them [119]. Most examples of TDA research emerge from physical, earth sciences, and engineering fields [24,35], and are often applied in a top-down manner [117].

The TDA approach of the Geo-Social Model seeks to fill this gap through the integration of epistemologically different disciplines-geology, social sciences, humanities—and the rescue of community-based resources. This is new, since TDA research carried out worldwide and in Latina America has its spotlight on science and technology stakeholders [35] or national policy makers capabilities $[120,121]$ in a general top-down manner. Despite this contribution, one of the main limitations of the research is the experimental and exploratory character of the mapping, and further research must be done in order to advance in the inclusion of geo-social features in landslides analysis and future hazard maps.

\section{Conclusions}

We developed what we labeled the Geo-Social Model to understand the interactions between geological processes, built interventions, and socio-cultural conditions in the formation and consequences of the 1993 landslide in Quebrada de Macul, Santiago. As an exploratory tool, this methodology brings together insights from the earth, social, planning, and engineering sciences to better understand and prevent socio-natural hazards in a process in which the community is not only the final recipient of the results, but the main actor defining the research questions, aims, and methods. While our exploration is placedependent, we claim that as a methodology the Geo-Social Model can be adapted to other territories and communities to advance in a more integrated research in landslides.

As a way of conclusion, we want to discuss three main challenges of landslide analysis and prevention that arise from our research process. First, flow-type landslidesparticularly in urban contexts-are often the result of anthropogenic disruptions of natural balances and systems. These interventions, in turn, are the effect of long histories of urbanization, infrastructuring, and occupation that, while exceeding the memory of current inhabitants, are passed intergenerationally and registered in the material and cultural trajectories of the community. If the so-called Anthropocene has been coined to call into attention the co-production of the geological and the social, then research into and inter- 
vention upon urban landslides in the Anthropocene has to account for the histories (and stories) of communities about the geological modifications of their environment.

Second, transdisciplinary approaches are critical for sustaining robust and politically. effective landslide risk prevention plans. What we learned in Quebrada de Macul is that this entails a re-accommodation of disciplinary identities. While earth scientists are required to integrate forms of evidence and narration coming from social sciences and the humanities that do not fit easily into 'scientific' accounts, social scientists have to engage with community demands, which usually revolve around 'hard' data about past and future events. Both earth and social scientists have to adapt their theories and methodologies to policy-oriented and often politically charged goals. Without the needed flexibility to meet these requirements, transdisciplinarity risks being mere tokenism, a sexy concept devoid from its epistemological and political implications.

Finally, inter- and trans-disciplinary approaches to landslide risk prevention need to be integrated into municipal-level planning. Without understanding the compound nature of landslides, and devising plans accordingly, landslides in Chile and elsewhere will continue to affect millions of people. In the case of the Global South, the lack of resources at the local level requires the implementation of ad-hoc programs at the state or federal level to channel professional and technological resources to municipalities, districts, or any other territorial subdivision. Fundamentally, it requires the empowerment of local communities to secure their substantial participation in landslide risk prevention plans: While governments often celebrate participation as arenas of encounter between communities and experts, they often forget that the first step is to create the conditions for community participation by restituting their political and territorial control.

Author Contributions: Conceptualization, M.T. and V.A.; methodology, F.R. and V.A.; software, F.R.; validation, F.R. and V.A.; formal analysis, F.R. and V.A.; investigation, V.A., L.J., and F.R.; resources, V.A., F.R., and L.J.; data curation, F.R. and V.A.; writing-original draft preparation, V.A., F.R., and M.T.; writing-review and editing, V.A., F.R., and M.T.; visualization, F.R.; supervision, M.T.; project administration, CIGIDEN; funding acquisition, CIGIDEN. All authors have read and agreed to the published version of the manuscript.

Funding: This research was funded by CIGIDEN (Center for Integrated Research on Disaster Risk Management) N 15110017 FONDAP 2011, and FONDECYT Nº 1190528.

Institutional Review Board Statement: Not applicable.

Informed Consent Statement: Not applicable.

Data Availability Statement: The data presented in this study are available on request from the corresponding author.

Acknowledgments: We thank the generosity of our collaborators and territorial organizations that actively work on the study area: Volunteer Forestry Brigade Alto La Florida (BEAF), National Forestry Corporation (CONAF), Defense Movement for access to Water, Land and the Protection of the Environment (MODATIMA), Alluvion Territorial Assembly (ATA), Intercultural Center Quebrada de Macul (CIQMA), Neighborhood Council "El Esfuerzo", Exclusion Zone leaderships, MAPUCHE community of Quebrada de Macul and the inhabitants of "Toma Dignidad". We also appreciate the technical assistance of Fernando Candia, the comments made by the geologist Matías Clunes and the sociologist Ricardo Rivas while we were carrying out the research; the dialogues established with foundation Proyecta Memoria -particularly with his director Víctor Orellana and the executive director Patricio Mora- and with Patricia Díaz, the creator and director of the web project "Disaster Archive". Finally, to CIGIDEN especially to L4 "Disaster culture and risk governance" and L1 "Solid Earth Process Threats".

Conflicts of Interest: The authors declare no conflict of interest and the funders had no role in the design of the study; in the collection, analyses, or interpretation of data; in the writing of the manuscript, or in the decision to publish the results. 


\section{Appendix A}

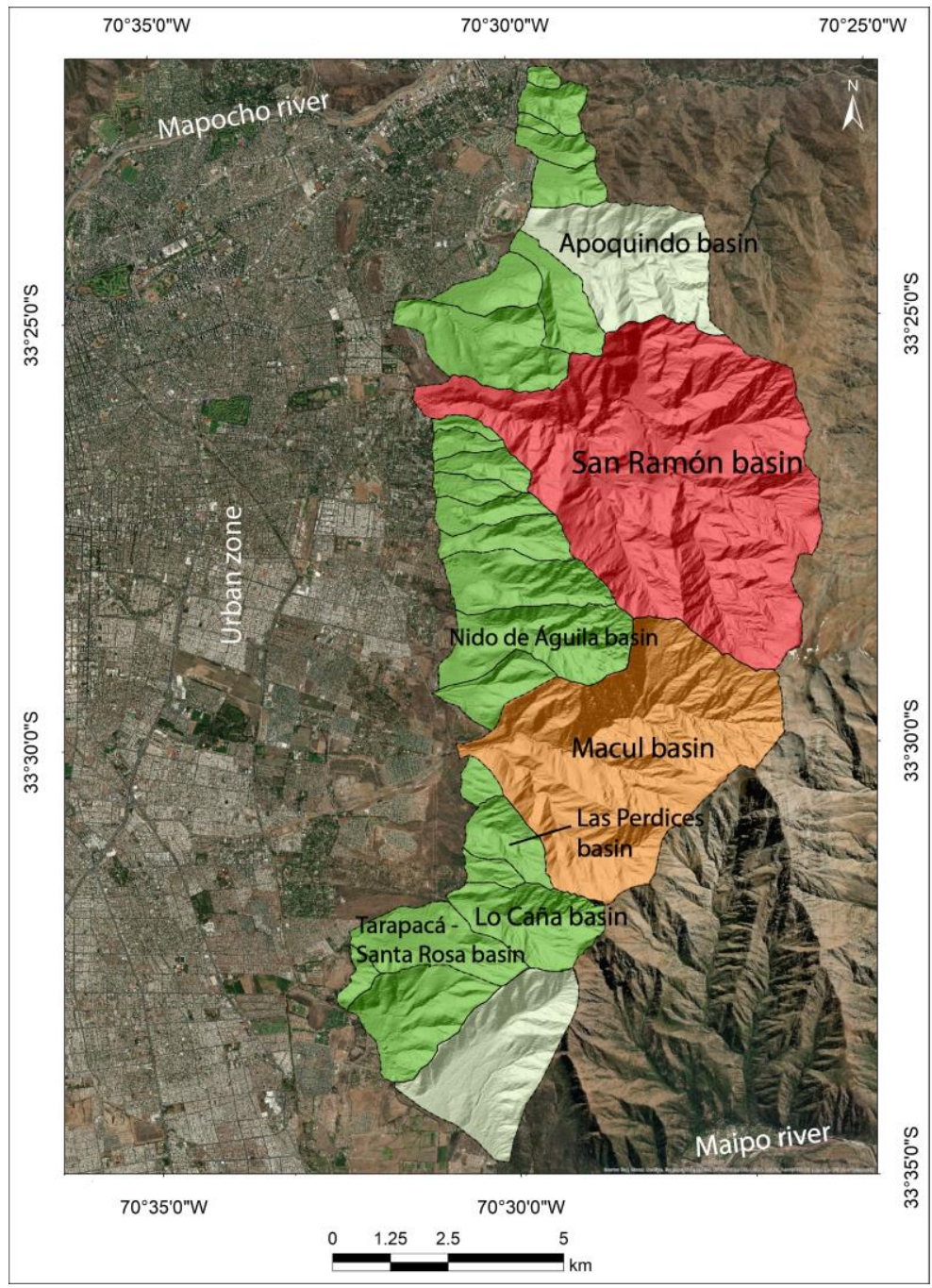

\section{Legend}

Classification by area of the hydrographic basin $\left(\mathrm{km}^{2}\right)$

\begin{tabular}{|ll}
$0.225-7.482 \quad-$ & Very small \\
$7.483-14.738 \quad-$ & Small \\
$14.739-21.994-$ & Median \\
$21.995-29.251-$ & Big \\
$29.252-36.507-$ & Very big
\end{tabular}

Figure A1. Map of classification by area of the hydrographic basin $\left(\mathrm{km}^{2}\right)$, in the eastern part of the city of Santiago (Chile).

\section{References}

1. Holcombe, E.A.; Beesley, M.E.; Vardanega, P.J.; Sorbie, R. Urbanisation and landslides: Hazard drivers and better practices. Proc. Inst. Civil Eng. Civil Eng. 2016, 169, 137-144. [CrossRef]

2. Schuster, R.L.; NietoThomas, A.S.; O’Rourke, T.D.; Crespo, E.; Plaza-Nieto, G. Mass wasting triggered by the 5 March 1987 Ecuador earthquakes. Eng. Geol. 1996, 42, 1-23. [CrossRef]

3. Dai, F.C.; Lee, C.F.; Ngai, Y.Y. Landslide risk assessment and management: An overview. Eng. Geol. 2002, 64, 65-87. [CrossRef]

4. Cui, Y.; Cheng, D.; Choi, C.E.; Jin, W.; Lei, Y.; Kargel, J.S. The cost of rapid and haphazard urbanization: Lessons learned from the Freetown landslide disaster. Landslides 2019, 16, 1167-1176. [CrossRef]

5. Petley, D.N.; Hearn, G.J.; Hart, A.; Rosser, N.J.; Dunning, S.A.; Oven, K.; Mitchell, W.A. Trends in landslide occurrence in Nepal. Nat. Hazards 2007, 43, 23-44. [CrossRef]

6. Garrido, N.; Sepúlveda, S.A. Peligro de flujos de detritos en Quebrada de Macul, Región Metropolitana y propuestas de medidas de mitigación. In Actas XIII Congreso Geológico Chileno. 2012, pp. 1012-1014. Available online: https://biblioteca.sernageomin.cl/ opac/DataFiles/14127_pp_1015_1017.pdf (accessed on 10 October 2020).

7. García-Soriano, D.; Quesada-Román, A.; Zamorano-Orozco, J.J. Geomorphological hazards susceptibility in high-density urban areas: A case study of Mexico City. J. S. Am. Earth Sci. 2020, 102, 102667. [CrossRef]

8. Dowling, C.A.; Santi, P.M. Debris flows and their toll on human life: A global analysis of debris-flow fatalities from 1950 to 2011. Nat. Hazards 2014, 71, 203-227. [CrossRef]

9. Ayala, L.; Cabrera, G.Y. Análisis de la Vulnerabilidad del Sector Oriente de la Capital de Santiago ante la Ocurrencia de Aluviones y Crecidas; Asociados Ltd.: Bogotá, Colombia, 1996. 
10. Biskupovic, C. Desnaturalizar lo natural. El aluvión de la Quebrada de Macul como proceso social en Santiago de Chile. Antropol. Sur. 2019, 6, 107-128. [CrossRef]

11. Inzulza, J.; Galleguillos, X. Latino gentrificación y polarización: Transformaciones socioespaciales en barrios pericentrales y periféricos de Santiago, Chile. Rev. Geogr. Norte Gd. 2014, 58, 135-159. [CrossRef]

12. Romero, H.; Vásquez, A. Evaluación ambiental del proceso de urbanización de las cuencas del piedemonte andino de Santiago de Chile. Rev. Eure 2005, 31, 97-117. [CrossRef]

13. Quintana, J.; Aceituno, P. Changes in the rainfall regime along the extratropical west coast of South America (Chile): $30-43^{\circ} \mathrm{S}$. Atmósfera 2012, 25, 1-22.

14. Fakvey, M.; Garreaud, R. Regional cooling in a warming world: Recent temperatura trends in the southeast Pacific and along the west coast of subtropical South America (1979-2006). J. Geophys. Res. 2009, 114. [CrossRef]

15. Bonelli, S.; Vicuña, S.; Meza, F.J.; Girońas, J.; Barton, J. Incorporating climate change adaption strategies in urban water supply planning: The case of central Chile. J. Water Clim. Chang. 2014, 5, 357-375. [CrossRef]

16. Gironás, J.; Sandoval, J. Riesgo de Origen Hidrometeorológico en la Ciudad de Santiago. 2016. Available online: https: / / docplayer.es / 48223960-Riesgo-de-origen-hidrometeorologico-en-la-ciudad-de-santiago.html (accessed on 10 October 2020).

17. Naranjo, J.A.; Varela, J. Flujos de Detritos y Barro que Afectaron el Sector Oriente de Santiago, el 3 de Mayo de 1993; Servicio Nacional de Geología y Minería: Providencia, Chile, 1996.

18. Vargas, X. Corrientes de detritos en la Quebrada de Macul, Chile. Estudio de caudales máximos. Ing. Agua 1999, 6, 341-344. [CrossRef]

19. Garreaud, R.; Rutllant, J. Análisis meteorológico de los aluviones de Antofagasta y Santiago de Chile en el periodo 1991-1993. Atmósfera 2009, 9, 251-271.

20. Gallardo, F.; Cabezas, K.B. Aluvión de la Quebrada Macul; Scribd: San Francisco, CA, USA, 2019.

21. Martínez, B.D. Susceptibilidad de Remoción en Masa en la Quebrada de Macul; Región Metropolitana: Santiago, Chile, 2009.

22. Cortés Rodríguez, G. El Escenario del Desastre: Parque Aluvial Quebrada de Macul. Reclamación del Paisaje de Infraestructuras Aluviales en la Precordillera Andina; Pontificia Universidad Católica de Chile: Santiago, Chile, 2019.

23. Rugiero, V.; Wyndham, K. Identificación de capacidades para la reducción de riesgo de desastre: Enfoque territorial de la participación ciudadana en la precordillera de comuna de La Florida, Santiago de Chile. Investig. Geogr. 2013, 46, 57. [CrossRef]

24. Alcántara-Ayala, I. On the multi-dimensions of integrated research on landslide disaster risk. In Landslides and Engineered Slopes. Experience, Theory and Practice: Proceedings of the 12th International Symposium on Landslides, Napoli, Italy, 12-19 June 2016; CRC Press: Boca Raton, FL, USA, 2018.

25. Anderson, M.G.; Holcombe, E.A. Community Based Landslide Risk Reduction: Managing Disasters in Small Steps; World Bank: Washington, DC, USA, 2013.

26. Anderson, M.G.; Holcombe, E.; Holm-Nielsen, N.; Della Monica, R. What Are the Emerging Challenges for Community-Based Landslide Risk Reduction in Developing Countries? Nat. Hazards Rev. 2014, 15, 128-139. [CrossRef]

27. United Nations. UN General Assembly Resoluion 46/182 of 19 December 1991. A/RES/46/182. 1991. Available online: http:/ / www.un.org/documents/ga/res/46/a46r182.htm (accessed on 25 November 2020).

28. Strategy, Y. Plan of Action for a Safer World-Guidelines for Natural Disaster Prevention, Preparedness and Mitigation. In Proceedings of the World Conference on Natural Disaster Reduction, Yokohama, Japan, 23-27 May 1994; pp. $23-27$.

29. United Nations. Report of the World Summit on Sustainable Development, Johannesburg, South Africa, 26 August-4 September 2002, New York, A/CONF.199/20. 2002. Available online: http://www.unmillenniumproject.org/documents/131302_wssd_ report_reissued.pdf (accessed on 25 November 2020).

30. Unisdr, U. Hyogo framework for action 2005-2015: Building the resilience of nations and communities to disasters. In Extract from the Final Report of the World Conference on Disaster Reduction (A/CONF. 206/6); International Strategy for Disaster Reduction: Geneva, Switzerland, 2005; 380p.

31. Icsu, A. Science Plan for Integrated Research on Disaster Risk: Addressing the Challenge of Natural and Human-Induced Environmental Hazards; International Council for Science: Paris, France, 2008.

32. UNISDR. Sendai Framework for Disaster Risk Reduction 2015-2030; UNISDR: Geneva, Switzerland, 2015.

33. McGlade, J.; Bankoff, G.; Abrahams, J.; Cooper-Knock, S.J.; Cotecchia, F.; Desanker, P.; Wood, M. Global Assessment Report on Disaster Risk Reduction; United Nations Office for Disaster Risk Reduction (UNDRR): Geneva, Switzerland, 2019.

34. Sassa, K. ISDR-ICL Sendai Partnerships 2015-2025 for global promotion of understanding and reducing landslide disaster risk. Landslides 2015, 12, 631-640. [CrossRef]

35. Matsuura, S.; Razak, K.A. Exploring transdisciplinary approaches to facilitate disaster risk reduction. Disaster Prev. Manag. 2019, 28, 817-830. [CrossRef]

36. Bonneuil, C.; Fressoz, J.B. The Shock of the Anthropocene: The Earth, History and Us; Verso Books: London, UK, 2016.

37. Malm, A. Fossil Capital: The Rise of Steam Power and the Roots of Global Warming; Verso Books: London, UK, 2016.

38. Clark, N.; Yusoff, K. Geosocial formations and the Anthropocene. Theory Cult. Soc. 2017, 34, 3-23. [CrossRef]

39. Braidotti, R.; Bignall, S. (Eds.) Posthuman Ecologies: Complexity and Process after Deleuze; Rowman \& Littlefield: Lanham, MD, USA, 2018.

40. Cohen, J.J. Stone: An Ecology of the Inhuman; University of Minnesota Press: Minneapolis, MN, USA, 2015.

41. Povinelli, E.A. Geontologies: A Requiem to Late Liberalism; Duke University Press: Durham, NC, USA, 2016. 
42. Nehren, U.; Sudmeier-Rieux, K.; Sandholz Merstrella, M.; Lomarda, M.; Guillén, T. The Ecosystem-Based Disaster Risk Reduction Case Study and Exercise Book, 1st ed.; PEDRR, CNRD: Cologne, Germany, 2014.

43. Lang, D.J.; Wiek, A.; Bergmann, M. Transdisciplinary research in sustainability science: Practice, principles, and challenges. Sustain. Sci. 2012, 7, 25-43. [CrossRef]

44. Gall, M.; Nguyen, K.H.; Cutter, S.L. Integrated research on disaster risk: Is it really integrated? Int. J. Disaster Risk Reduct. 2015, 12, 255-267. [CrossRef]

45. Muhar, A.; Visser, J.; Van Breda, J. Experiences from establishing structured inter-and transdisciplinary doctoral programs in sustainability: A comparison of two cases in South Africa and Austria. J. Clean. Prod. 2013, 61, 122-129. [CrossRef]

46. Censo, I.N.E.I. Chile. Revista Virtual. 2017. Available online: https://www.censo2017.cl (accessed on 31 March 2019).

47. Pliscoff, P. Análisis del Estado Actual de los Ecosistemas Terrestres, Asociados a dos Cuencas en Chile Central: Maipo y Maule. Escenarios Hídricos Chile 2030. 2020. Available online: https:/ fch.cl/wp-content/uploads/2020/08/estado-ecosistemas-maulemaipo-eh2030-pliscoff.pdf (accessed on 10 October 2020).

48. Münzenmayer, J. La expansión urbana y la segregación socio-espacial en Santiago. Dimensiones territoriales del fenómenos contemporáneo. Rev. Geogr 2017, 4-21. [CrossRef]

49. Turner, S.F.; Cardinal, L.B.; Burton, R.M. Research design for mixed methods: A triangulation-based framework and roadmap. Organ. Res. Methods 2017, 20, 243-267. [CrossRef]

50. Jick, T.D. Mixing qualitative and quantitative methods: Triangulation in action. Adm. Sci. Q. 1979, 24, 602-611. [CrossRef]

51. Bezinska, G.; Stoyanov, K. Modelling and hydro-morphometric analysis of sub-watershed. A case study of Mesta river southwestern Bulgaria. Eur. J. Geogr. 2019, 10, 77-88.

52. Cruden, D.; Varnes, D.J. Landslide Types and Processes. In Landslides: Investigation and Mitigation; Turner, A.K., Schuster, R.L., Eds.; National Academy Press: Washington, DC, USA, 1996; pp. 36-75.

53. Bathrellos, G.; Skilodimou, H.; Chousianitis, K.; Youssef, A.; Pradhan, B. Suitability estimation for urban development using multi-hazard assessment map. Sci. Total Environ. 2017, 575, 119-134. [CrossRef] [PubMed]

54. Hauser, A. Flujos de Barro en la Zona Preandina de la Región Metropolitana: Características, Causas, Efectos, Riesgos y Medidas Preventivas. Rev. Geol. Chile 1985, 24, 75-92.

55. Liem, N.; Bui, D. Assessment of geomorphic processes and active tectonics in Con Voi mountain range area (Northern Vietnam) using the hypsometric curve analysis method. Vietnam J. Earth Sci. 2016, 38, 202-216. [CrossRef]

56. López, F.; Romero, M. Morfometría de Redes Fluviales: Revisión Crítica de los Parámetros más Utilizados y Aplicación al Alto Guadarquivir; Universidad de Murcia: Murcia, Spain, 1987.

57. SGC. Propuesta Metodológica Sistemática Para la Generación de Mapas Geomorfológicos Analíticos Aplicados a la Zonificación de Amenaza por Movimientos en Masa Escala 1:100,000; Servicio Geológico Colombiano: Bogotá, Colombia, 2012; p. 90.

58. Lara, M.; Sepúlveda, A.; Rebolledo, S. Geología y Geotecnia para la Evaluación de Peligro de Remociones en Masa en Quebrada San Ramón, Santiago Oriente; XI Congreso Geológico Chileno: Actas, Colombia, 2006; Volume 2.

59. Thiele, C.; Santiago, R.H. Santiago de Chile; Esc. 1:250,000. Color; Instituto de Investigaciones Geológicas: Santiago, Chile, 1980.

60. Moreno, H.; Thiele, R. Estudio Geológico y de Riesgos Volcánicos y de Remoción en Masa del Proyecto Hidroeléctrico Alfalfal II-Las Lajas; Departamento de Geología y Física, Universidad de Chile: Santiago, Chile, 1991.

61. Yin, R.K. Qualitative Research from Start to Finish; Guilford Publications: New York, NY, USA, 2015.

62. Creswell, J.W.; Poth, C.N. Qualitative Inquiry and Research Design: Choosing among Five Approaches; Sage Publications: Thousand Oaks, CA, USA, 2016.

63. Denzin, N.K.; Lincoln, Y.S. (Eds.) The Sage Handbook of Qualitative Research; Sage: Thousand Oaks, CA, USA, 2011.

64. Vitorelli Diniz Lima Fagundes, K.; Almeida Magalhães, A.D.; dos Santos Campos, C.C.; Garcia Lopes Alves, C.; Mônica Ribeiro, P.; Mendes, M.A. Hablando de la Observación Participante en la investigación cualitativa en el proceso salud-enfermedad. Index Enfermería 2014, 23, 75-79. [CrossRef]

65. Mason, J. Qualitative Researching; Sage: Thousand Oaks, CA, USA, 2017.

66. Horton, R. Drainage-Basin Characteristics; Transactions American Geophysical Union: Washington, DC, USA, $1932 ;$ pp. $350-361$.

67. Gaspari, F.; Rodríguez, A.; Senisterra, G.; Denegri, G.; Delgado, M.; Besteiro, S. Morphometric Characterization of the Upper Watershed of the Sauce Grande River, Buenos Aires, Argentina; CONGRESO DE MEDIO AMBIENTE AUGM. 22 al 24 de mayo de 2012; Universidad Nacional de la Plata: La Plata, Argentina, 2012; p. 25.

68. Strahler, A. Quantitative geomorphology of drainage basins and channel networks. In Handbook of Applied Hydrology; Chow, V., Ed.; Mc Graw-Hill: New York, NY, USA, 1964; pp. 439-476.

69. Gil, V.; Gentili, J.; Campo, A. Influencia de la Litología en la Variación de los Parámetros Morfométricos, Sistema de Ventana, Argentina. Universidad Nacional del Sur-CONICET. Bahía Blanca, Argentina. Pap. Geogr. 2009, 49-50, 55-68.

70. Senciales, J.M. Redes Fluviales. Metodología de Análisis; Editorial Universidad de Málaga, Servicio de Publicaciones e Intercambios: Málaga, Spain, 1999; p. 337.

71. Sala, M.; Gay, R. Algunos datos morfométricos de la Cuenca del Isadora. Notes Geogr. Fís. 1981, 4, 41-65.

72. Sánchez, T. Estudio Morfoclimático del CabeVó D'OR; Universidad de Alicante: Alicante, Spain, 1991; p. 69.

73. Guerra, F.; González, J. Caracterización morfométrica de la cuenca de la quebrada la Bermeja, San Cristóbal, Estado Táchira, Venezuela. Geoenseñanza 2002, 7, 88-108. 
74. Aracena, I. Determinación de Riesgo por Flujos de Escombros en la Ciudad de Antofagasta; Universidad Católica de Chile: Santiago, Chile, 1993.

75. Garay, D.; Agüero, J. Delimitación Hidrográfica y Caracterización Morfométrica de la Cuenca del Río Anzulón; Instituto Nacional de Tecnología Agropecuaria. Ministerio de Agroindustria: La Rioja, Argentina, 2018.

76. Börgel, R. Un Método para la Prevención de Aluviones en Zonas Desérticas. Presentado en SIPAC 1978; Instituto de Geografía Pontificia Universidad Católica de Chile: Santiago, Chile, 1978.

77. Millán, M. Cauces Urbanos y Parques Inundables. Dirección de Obras Hidráulicas, Ministerio de Obras Públicas. 2014. Available online: http:/ / www.cedeus.cl/wp-content/uploads/2014/08/MMillan_DOH.pdf (accessed on 1 February 2021).

78. Asociación de Canalistas del Maipo. 180 Años Sociedad del Canal del Maipo 1827-2007; Asociación de Canalistas Sociedad del Canal de Maipo: Maipo, Chile, 2015.

79. AHN. Plano del Terreno Comprendido entre la Cuidad de Santiago y el Río Maipo con Diversos Proyectos para Traer Agua Desde alto río Hasta la Cuidad/José Pizarro [Material Cartográfico]. 1742. Available online: http:/ /www.bncatalogo.gob.cl/F/ U45XAUQJTC2DJMPYR57A75RMBR41CVBPEMR8DQ3EAGB1BD6G3V-39505? func=full-set-set\&set_number=006801\&set_ entry $=000003 \&$ format $=999$ (accessed on 13 October 2020).

80. Borja Solar, F. Plano de la Chacra Macul de la Testamentaria de Doña Mercedes Gandarillas de Larrain [Map]. Available online: https: / / www.bibliotecadigital.uchile.cl/discovery/delivery/56UDC_INST:56UDC_INST/12173307140003936 (accessed on 10 October 2020).

81. National Library of Chile. El Chileno Newspaper. Date: 17 August 1899 [authors transcription]. 1899.

82. Forray, R.; Figueroa, C.; Hidalgo, R. De Camino del Inca a Gran Avenida. ARQ 2013, 85, 36-47. [CrossRef]

83. National Library of Chile. La Nación Newspaper. Date: 5 June 1993 [authors transcription]. 1993.

84. National Library of Chile. La Nación Newspaper. Date: 6 June 1993 [authors transcription]. 1993.

85. Corvalán, N.; Kovacic, I.; Muñoz, O. Quebrada de Macul: El aluvión del 3 de mayo 1993. Causas y consecuencias. Rev. Geogr. Chile Terra Aust. 1997, 42, 139-167.

86. Muñoz, O. Quebrada de Macul: Un factor de desequilibrio físico en la comuna de la Florida. Revista Geogr. Chile Terra Aust. 1990, 32, 103-134.

87. Beyá, R. Prácticas de Apropiación y Significados Atribuidos al Paisaje Fluvial en Riesgo y su Incidencia en la Vulnerabilidad ante Desastres Socionaturales. Caso de Estudio: El Parque Natural Quebrada de Macul; Tesis para Obtener el Grado Académico de Magister en Asentamientos Humanos y Medio Ambiente; Instituto de Estudios Urbanos y Territoriales Pontificia Universidad Católica de Chile: Santiago, Chile, 2019.

88. Sepúlveda, S.A. Metodología para Evaluar el Peligro de Flujos de Detritos en Ambientes Montañosos: Aplicación en la Quebrada Lo Cañas, Región Metropolitana; Memoria para optar al Título de Geólogo; Departamento de Geología, Universidad de Chile: Santiago, Chile, 1998.

89. SERVIU. Resolución Exenta 01467. 2016.

90. SERVIU. Ordenanza Plan Regulador Metropolitano de Santiago Texto Actualizado y Compaginado. 2007. Available online: https: / / docplayer.es / 8618038-Ordenanza-plan-regulador-metropolitano-de-santiago-texto-actualizado-y-compaginado.html (accessed on 10 October 2020).

91. Chile's Oficial Newspaper. Date: 8 October 2019. Available online: https://www.laflorida.cl/sitio/wp-content/uploads/2020/0 5/Publicacion-Diario-Oficial_Inicio-EAE-Modificacion-PRC-La-Florida.pdf (accessed on 10 October 2020).

92. Cotroneo, J.; Montserrat, G.; Montserrat, S.; Niño, Y.; Tamburrino, A. Modelo Físico de Obras de Desvío Aluvional; XXVIII Congreso Latinoamericano de Hidráulica; Quebrada de Macul, Región Metropolitana: Peñalolén, Chile, 2018.

93. Informe Consolidado de la Evaluación de Impacto Ambiental de la Declaración de Impacto Ambiental del Proyecto Obras para el Control de Aluviones y Arrastre de Sedimentos en Quebrada de Macul, Región Metropolitana. Available online: https: / /infofirma.sea.gob.cl/DocumentosSEA/MostrarDocumento?docId=28/41/7e0dcd79545d1d3ad4adcccfe82133b41de4 (accessed on 10 October 2020).

94. Silva Vargas, F. Tierras y Pueblos de Indios en el Reino de Chile: Esquema Historico-Juridico. Ph.D. Thesis, Universidad Católica de Chile, Santiago, Chile, 1962.

95. Echaiz, R.L. Ñuñohue: Historia de Ñuñoa, Providencia, Las Condes y La Rheina; Editorial Francisco de Aguirre: Buenos Aires, Argentina, 1972; Volume 40.

96. Stehberg, R.; Sotomayor, G. Mapocho incaico. Boletín Mus. Nac. Hist. Nat. 2012, 61, 85-149.

97. Territorial Guide for the Reduction of the Risk of Emergencies and Disasters 2018-2019; Municipalidad de la Florida: La Florida, Chile, 2018.

98. Varnes, D.J. Slope movement types and processes. Spec. Rep. 1978, 176, 11-33.

99. Hauser, A. Remociones en Masa en Chile. Boletín No59; Servicio Nacional de Geología y Minería: Santiago, Chile, 2000.

100. Proyecto Multinacional Andino. Movimientos en Masa en la Región Andina: Una Guía para la Evaluación de Amenazas. Geociencias para las Comunidades Andinas; Segemar: Buenos Aires, Argentina, 2007.

101. Oldrich, H.; Serge, L.; Luciano, P. The Varnes classification of landslide types, an update. Landslides 2014.

102. Garrido, N. Determinación de Peligro de Flujos de Detritos en la Quebrada de Macul, Cuenca de Santiago. Thesis to Qualify for the Title of Geologist. Departamento de Geología. Universidad de Chile. 2009. Available online: http://repositorio.uchile.cl/ handle/2250/111565 (accessed on 10 October 2020). 
103. SafeLand: Deliverable 4.8: Guidelines for Landslide Monitoring and Early Warning Systems in Europe: Design and Required Technology; SafeLand: Stockholm, Sweden, 2011.

104. Jaboyedoff, M.; Michoud, C.; Derron, M.H.; Voumard, J.; Leibundgut, G.; Sudmeier-Rieux, K.; Leroi, E. Human-Induced landslides: Toward the Analysis of Anthropogenic Changes of the Slope Environment. Landslides and Engineered Slopes. Experience, Theory and Practice; CRC Press: Boca Raton, FL, USA, 2018; pp. 217-232.

105. Preuth, T.; Glade, T.; Demoulin, A. Stability analysis of a human-influenced landslide in eastern Belgium. Geomorphology 2010, 120, 38-47. [CrossRef]

106. Zêzere, J.L.; de Brum Ferreira, A.; Rodrigues, M.L. The role of conditioning and triggering factors in the occurrence of landslides: A case study in the area north of Lisbon. Geomorphology 1999, 30, 133-146. [CrossRef]

107. Sah, M.P.; Mazari, R.K. Anthropogenically accelerated mass movement, Kulu Valley, Himachal Pradesh, India. Geomorphology 1998, 26, 123-138. [CrossRef]

108. Sepúlveda, S.A.; Petley, D.N. Regional trends and controlling factors of fatal landslides in Latin America and the Caribbean. Nat. Hazards Earth Syst. Sci. 2015, 15, 1821-1833. [CrossRef]

109. Dodman, D.; Mitlin, D. Challenges for community-based adaptation: Discovering the potential for transformation. J. Int. Dev. 2013, 25, 640-659. [CrossRef]

110. García-Martínez, R.; López, J.L. Debris flows of December 1999 in Venezuela. In Debris-Flow Hazards and Related Phenomena; Springer: Berlin/Heidelberg, Germany, 2005.

111. Alexander, D. Vulnerability to landslides. In Landslide Hazard Risk; Wiley: Chichester, UK, 2005; pp. 175-198.

112. Ullberg, S. Disaster memoryscapes: How social relations shape community remembering of catastrophe. Anthropol. News 2010, 51, 12-15. [CrossRef]

113. Ullberg, S. Watermarks: Urban Flooding and Memoryscape in Argentina. Acta Univ. Stockh. 2013. Available online: https: / / www.academia.edu/4019701/Watermarks_Urban_Flooding_and_Memoryscape_in_Argentina (accessed on 10 October 2020).

114. Baez Ullberg, S. Desastre y Memoria Material: La Inundación 2003 en Santa Fe, Argentina. Iberoam. Nord. J. Lat. Am. Caribb. Stud. 2017, 46, 42-53. [CrossRef]

115. Masi, M.B. Watermarks. Urban Flooding and Memoryscape in Argentina. Pampa. 2014, pp. 265-268. Available online: https:/ / biblat.unam.mx/pt/revista/pampa-santa-fe/articulo/ullberg-s-watermarks-urban-flooding-and-memoryscape-inargentina-2013-estocolmo-acta-universitatis-stockholmiensis-stockholm-university-library-2013 (accessed on 10 October 2020).

116. Carey, M.; McDowell, G.; Huggel, C.; Jackson, J.; Portocarrero, C.; Reynolds, J.M.; Vicuña, L. Integrated approaches to adaptation and disaster risk reduction in dynamic socio-cryospheric systems. In Snow and Ice-Related Hazards, Risks and Disasters; Haeberli, W., Whiteman, C., Eds.; Elsevier: Amsterdam, The Netherlands, 2015; pp. 219-261.

117. Frey, H.; Huggel, C.; Bühler, Y.; Buis, D.; Burga, M.D.; Choquevilca, W.; Masias, P.A. Robust debris-flow and GLOF risk management strategy for a data-scarce catchment in Santa Teresa, Peru. Landslides 2016, 13, 1493-1507. [CrossRef]

118. Takeuchi, K.; Momo, R.; Tsukahara, K. Transdisciplinary Approach for Building Societal Resilience to Disasters-Vision, Strategy and Envisioned Activities of TC21; Japan Society of Civil Engineers (JSCE), Technical Committee Paper for Asian Civil Engineering Coordinating Council (ACECC): Tokyo, Japan, 2016.

119. Van Breda, J. Transdisciplinarity; Peri Peri U: London, UK, 2012; pp. 1-34.

120. Hardoy, J.; Pandiella, G.; Barrero, L.S.V. Local disaster risk reduction in Latin American urban areas. Environ. Urban. 2011, 23, 401-413. [CrossRef]

121. Murti, R.; Mathez-Stiefel, S.L. Social learning approaches for ecosystem-based disaster risk reduction. Int. J. Disaster Risk Reduct. 2019, 33, 433-440. [CrossRef] 